\title{
Impact of emission changes on secondary inorganic aerosol episodes across Germany
}

\author{
S. Banzhaf ${ }^{1}$, M. Schaap ${ }^{2}$, R. J. Wichink Kruit ${ }^{2}$, H. A. C. Denier van der Gon ${ }^{2}$, R. Stern ${ }^{1}$, and P. J. H. Builtjes ${ }^{1,2}$ \\ ${ }^{1}$ Institut für Meteorologie, Freie Universität Berlin, Carl-Heinrich-Becker Weg 6-10, 12165 Berlin, Germany \\ ${ }^{2} \mathrm{TNO}$, Department Climate, Air Quality and sustainability, Princetonlaan 6, 3508 TA Utrecht, the Netherlands
}

Correspondence to: S. Banzhaf (sabine.banzhaf@met.fu-berlin.de)

Received: 29 April 2013 - Published in Atmos. Chem. Phys. Discuss.: 14 June 2013

Revised: 16 October 2013 - Accepted: 28 October 2013 - Published: 3 December 2013

\begin{abstract}
In this study, the response of secondary inorganic aerosol (SIA) concentrations to changes in precursor emissions during high $\mathrm{PM}_{10}$ episodes over central Europe in spring 2009 was investigated with the Eulerian Chemistry Transport Model (CTM) REM-Calgrid (RCG). The model performed well in capturing the temporal variation of $\mathrm{PM}_{10}$ and SIA concentrations and was used to analyse the different origin, development and characteristics of the selected high $\mathrm{PM}_{10}$ episodes. SIA concentrations, which contribute to about $50 \%$ of the $\mathrm{PM}_{10}$ concentration in northwestern Europe, have been studied by means of several model runs for different emission scenarios. $\mathrm{SO}_{2}, \mathrm{NO}_{\mathrm{x}}$ and $\mathrm{NH}_{3}$ emissions have been varied within a domain covering Germany and within a domain covering Europe. It was confirmed that the response of sulfate, nitrate and ammonium concentrations and deposition fluxes of $\mathrm{S}$ and $\mathrm{N}$ to $\mathrm{SO}_{2}, \mathrm{NO}_{\mathrm{x}}$ and $\mathrm{NH}_{3}$ emission changes is non-linear. The deviation from linearity was found to be lower for total deposition fluxes of $\mathrm{S}$ and $\mathrm{N}$ than for SIA concentrations. Furthermore, the study has shown that incorporating explicit cloud chemistry in the model adds non-linear responses to the system. It significantly modifies the response of modelled SIA concentrations and $\mathrm{S}$ and $\mathrm{N}$ deposition fluxes to changes in precursor emissions. The analysis of emission reduction scenario runs demonstrates that next to European-wide emission reductions additional national $\mathrm{NH}_{3}$ measures in Germany are more effective in reducing SIA concentrations and deposition fluxes than additional national measures on $\mathrm{SO}_{2}$ and $\mathrm{NO}_{\mathrm{x}}$.
\end{abstract}

\section{Introduction}

Particulate matter has adverse impact on public health (Pope et al., 2007, 2008). The European Commission established directives regarding $\mathrm{PM}_{10}$ concentration level to avoid, prevent or reduce harmful effects on human health (European Commission, 2008). The analysis of observations reveals that the current EU limit values for $\mathrm{PM}_{10}$ are still exceeded over large parts of Europe (EEA, 2012) indicating a continued need for further implementation of abatement strategies. Secondary inorganic aerosol (=SIA: $\mathrm{SO}_{4}^{2-}, \mathrm{NO}_{3}^{-}$and $\mathrm{NH}_{4}^{+}$) originating from gaseous precursors such as $\mathrm{SO}_{2}, \mathrm{NO}_{\mathrm{x}}$ and $\mathrm{NH}_{3}$ (Fountoukis and Nenes, 2007) comprises an important fraction of $\mathrm{PM}_{10}$. Experimental studies have shown that in the rural background the average $\mathrm{PM}_{10}$ is dominated by SIA contribution (Van Dingenen et al., 2004; Putaud et al., 2004). Moreover, during PM episodes the fraction of SIA is higher than on average (Weijers et al., 2011). After removal of SIA and its precursors from the atmosphere they contribute to eutrophication and acidification of soils and water bodies with harmful effects to vulnerable ecosystems (Bobbink et al., 1998).

SIA is dominated by ammonium-sulfate and ammoniumnitrate salts (Putaud et al., 2010). The precursor gases $\mathrm{NO}_{\mathrm{x}}$ and $\mathrm{SO}_{2}$ are oxidised to form $\mathrm{HNO}_{3}$ and $\mathrm{H}_{2} \mathrm{SO}_{4}$, respectively. Ammonium-sulfate and ammonium-nitrate are then formed when nitric acid and sulfuric acid are neutralised by $\mathrm{NH}_{3}$. In contrast to ammonium-sulfate, ammonium-nitrate is a semi-volatile component (Nenes et al., 1999). $\mathrm{NH}_{3}$ preferentially neutralizes sulfuric acid due to its low saturation vapour pressure. If abundant $\mathrm{NH}_{3}$ is available, ammoniumnitrate may form. The thermodynamic equilibrium between 
gas and aqueous aerosol phase is determined by temperature, relative humidity and the ambient concentrations of sulfate, total nitrate and total ammonia (West et al., 1999). In addition, $\mathrm{NH}_{3}$ constrains cloud droplet $\mathrm{pH}$, which regulates the oxidation pathway of $\mathrm{SO}_{2}$ and therewith the formation efficiency of sulfate (Fowler et al., 2007). Furthermore, the dry deposition velocities of $\mathrm{NH}_{3}$ and $\mathrm{SO}_{2}$ are connected (Fowler et al., 2001). Hence, emission reductions of gaseous SIA precursors lead to shifts in the equilibrium and affect the formation, residence time and removal of sulfur and nitrogen compounds and result in a non-linear response of the SIA concentrations (Fagerli and Aas, 2008). The impact of the complex interactions varies seasonally and regionally over Europe with changing emission regime.

Among emission changes of $\mathrm{SO}_{2}, \mathrm{NO}_{\mathrm{x}}$ and $\mathrm{NH}_{3}$, responses to $\mathrm{NH}_{3}$ emission changes show the largest non-linear behaviour (Tarrasón et al., 2003). Former studies over Europe regarding responses of ambient PM levels to emission reductions indicate that a decrease of $\mathrm{NH}_{3}$ emissions may entail a high reduction potential for SIA (and therewith PM) concentrations and deposition fluxes of S and N (e.g. Erisman and Schaap, 2004; Derwent et al., 2009; Redington et al., 2009; Matejko et al., 2009). Pinder et al. (2007) found that reducing $\mathrm{NH}_{3}$ emissions may offer significant cost savings compared to further controls on $\mathrm{SO}_{2}$ and $\mathrm{NO}_{\mathrm{x}}$ (in the US). In contrast, other studies indicated that for regions, in which SIA formation is $\mathrm{SO}_{2}$ - and $\mathrm{HNO}_{3}$-limited due to high $\mathrm{NH}_{3}$ concentrations, a decrease in $\mathrm{SO}_{2}$ and $\mathrm{NO}_{\mathrm{x}}$ emissions may result in a large reduction of SIA concentrations (Pay et al., 2012; de Meij et al., 2009). Further research is needed to consider and include the impact of the non-linear system described above in current $\mathrm{PM}_{10}$ mitigation strategies.

So far, investigations on the impact of emission reductions of precursors $\mathrm{SO}_{2}, \mathrm{NO}_{\mathrm{x}}$ and $\mathrm{NH}_{3}$ on SIA or PM concentrations focussed on long-term trends (Fagerli and Aas, 2008; Fowler et al., 2005; Lövblad et al., 2004; Erisman et al., 2003), on the analysis of one specific year (Tarrasón et al., 2003; Derwent et al., 2009) or on separate months (Erisman and Schaap, 2003; Renner and Wolke, 2010; de Meij et al., 2009), but not on specific periods with elevated $\mathrm{PM}_{10}$ levels. During the last decade, springtime high $\mathrm{PM}_{10}$ episodes were repeatedly reported in large areas over Europe with $\mathrm{PM}_{10}$ concentrations above $100 \mu \mathrm{g} \mathrm{m}^{-3}$ (e.g. 2006, 2007, 2009 and 2011). Springtime is marked by periods of fair weather with medium temperatures combined with high $\mathrm{NH}_{3}$ emission due to incipient agricultural activity. The latter leads to high $\mathrm{NH}_{3}$ availability, which enhances SIA formation.

In this study, the development and characteristics of two high $\mathrm{PM}_{10}$ episodes over central Europe in spring 2009 are studied. Furthermore, the response of modelled SIA concentrations to changes in the precursor emission is investigated for this time period. With respect to the latter, the sensitivity of modelled SIA concentrations to changes in $\mathrm{NH}_{3}$ emissions is investigated. Furthermore, SIA concentrations are calculated for different scenario runs with simultaneously varying
$\mathrm{SO}_{2}, \mathrm{NO}_{\mathrm{x}}$ and $\mathrm{NH}_{3}$ emissions. A critical question for national policy makers is how much reduction in population exposure can be achieved by national measures versus generic European measures. We define measures in the German national domain and compare the impact with European-wide measures. Therefore, for each scenario run, two cases were simulated: in the first case the emission scenario runs were only applied to the model domain covering Germany, and in the second case, the emission scenario runs were also applied to the European model domain, which provides the boundary conditions for the national domain. Besides SIA concentrations, deposition fluxes of $\mathrm{S}$ and $\mathrm{N}$ are also included in the analysis. Deposition fluxes are important sinks for SIA and the air concentrations of its precursor gases.

In the following section, the model and observations are described. A detailed overview of the model set up and the performed emission scenario runs is given. In Sect. 3, the investigation period is described. In the subsequent section (Sect. 4) the characteristics of the PM episodes in spring 2009 and results of the model evaluation and the emission scenario runs are presented. The results are discussed and conclusions are drawn in Sect. 5.

\section{Methods and data}

\subsection{Model description and set-up}

The Eulerian grid model REM-Calgrid (RCG) simulates air pollution concentrations solving the advection-diffusion equation on a regular latitude-longitude-grid with variable resolution over Europe (Beekmann et al., 2007; Stern, 2006). RCG is offline-coupled to the German Weather Service operational NWP model COSMO-EU (Schättler et al., 2008). The vertical transport and diffusion scheme accounts for atmospheric density variations in space and time and for all vertical flux components. For the horizontal advection of pollutants the advection scheme developed by Walcek (2000) is used. Gas-phase chemistry is simulated using an updated version of the photochemical reaction scheme CBM-IV (Gery et al., 1989), including Carter's 1-product isoprene scheme (Carter, 1996), as described in Gipson and Young (1999). Furthermore, RCG features thermodynamic equilibrium modules for secondary inorganic aerosols (ISORROPIA: Nenes et al., 1999) and organic aerosols (SORGAM: Schell et al., 2001). RCG includes modules to treat the emissions of sea salt aerosols (Gong et al., 1997) and wind-blown dust particles (Claiborn et al., 1998; Loosemore und Hunt, 2000). Dry deposition fluxes are calculated following a resistance approach as proposed by Erisman et al. (1994).

RCG is used within Germany to evaluate emission reduction strategies for the German government (PAREST; Builtjes et al., 2010). Moreover, RCG is one of the models that are used to benchmark the EMEP model against within the 


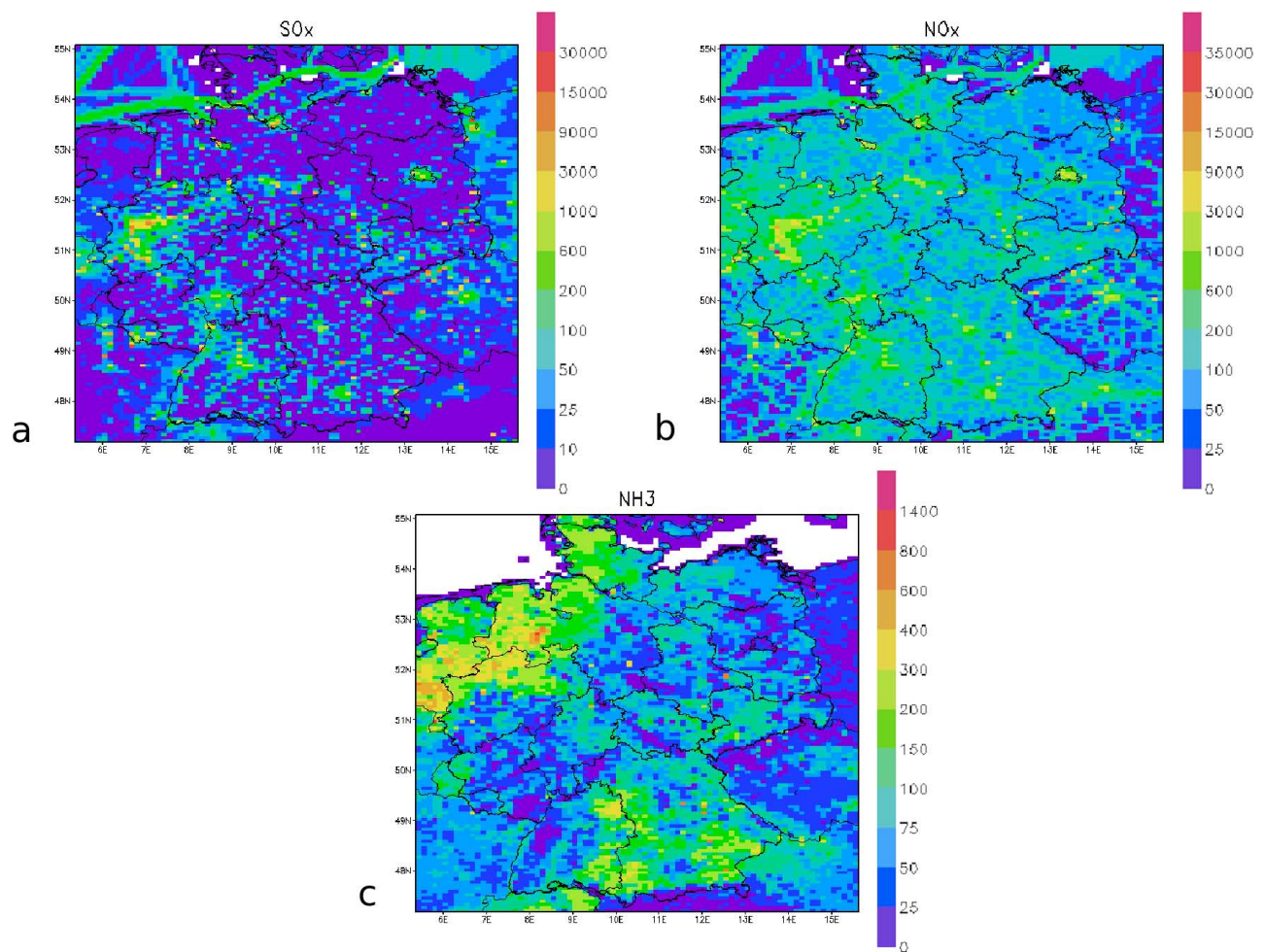

Fig. 1. Spatial distribution of the total annual (a) $\mathrm{SO}_{\mathrm{x}}$, (b) $\mathrm{NO}_{\mathrm{x}}$ and (c) $\mathrm{NH}_{3}$ emissions in $\mathrm{ta}^{-1}$ cell ${ }^{-1}$.

Table 1. Overview of performed emission reduction scenario runs and their set-up.

\begin{tabular}{lcccc}
\hline Scenario runs & $\begin{array}{c}\mathrm{pH} \\
\text { modelled }\end{array}$ & $\begin{array}{c}\mathrm{pH} \\
\text { constant }\end{array}$ & $\begin{array}{c}\text { German } \\
\text { domain (GD) }\end{array}$ & $\begin{array}{c}\text { European } \\
\text { domain (ED) }\end{array}$ \\
\hline base run & $\mathrm{x}$ & - & $\mathrm{x}$ & $\mathrm{x}$ \\
$-40 \% \mathrm{NH}_{3}$ & $\mathrm{x}$ & - & $\mathrm{x}$ & $\mathrm{x}$ \\
$-20 \% \mathrm{NO}_{\mathrm{x}}-50 \% \mathrm{SO}_{2}$ & $\mathrm{x}$ & - & $\mathrm{x}$ & $\mathrm{x}$ \\
$-40 \% \mathrm{NH}_{3}-20 \% \mathrm{NO}_{\mathrm{x}}-50 \% \mathrm{SO}_{2}$ & $\mathrm{x}$ & - & $\mathrm{x}$ & $\mathrm{x}$ \\
\hline
\end{tabular}

Task Force on Measurements and Modelling (TFMM) EURODELTA (Vautard et al., 2009) studies.

For this study, a research version of RCG was used as described in Banzhaf et al. (2012). It includes enhanced physical and chemical descriptions of scavenging processes and sulfate production as a function of cloud liquid water content and cloud/rain droplet $\mathrm{pH}$. Cloud droplet $\mathrm{pH}$ is estimated using the concentrations of the (strong) acids and bases, including the buffering by bi-carbonate (through $\mathrm{CO}_{2}$ ). For the formation of sulfate in cloud water the oxidation of dissolved $\mathrm{SO}_{2}$ by hydrogen peroxide and ozone are simulated. Sulfate formation and wet scavenging can either be calculated using modelled droplet $\mathrm{pH}$ or using a constant droplet $\mathrm{pH}$. Banzhaf et al. (2012) showed that a modelled droplet $\mathrm{pH}$ gives a better model performance and better model consistency concerning air concentrations and wet deposition fluxes than a constant $\mathrm{pH}$. The RCG wet deposition scheme distinguishes between in-cloud and below-cloud scavenging of gases and particles.
The applied scheme integrates wet deposition throughout the column.

The model runs for spring 2009 were performed on a domain covering Germany $\left(47.2^{\circ} \mathrm{N}-55.1^{\circ} \mathrm{N} ; 5.4^{\circ} \mathrm{E}-15.7^{\circ} \mathrm{E}\right)$, in the following referred to as the German domain (GD), with a horizontal resolution of approximately $7 \times 7 \mathrm{~km}^{2}$ and 20 vertical layers up to $5000 \mathrm{~m}$. An RCG run covering Europe $\left(35.1^{\circ} \mathrm{N}-66.3^{\circ} \mathrm{N} ; 10.2^{\circ} \mathrm{W}-30.8^{\circ} \mathrm{E}\right)$, in the following referred to as the European domain (ED), provided the boundary conditions. Emissions for Germany were taken from a national inventory for the year 2005 (Appelhans et al., 2012, Builtjes et al., 2010) and combined with the European TNOMACC (Monitoring Atmospheric Composition and Climate) data set for the same year (Denier van der Gon et al., 2010; Kuenen et al., 2011). The spatial distributions of the total annual $\mathrm{NH}_{3}, \mathrm{SO}_{\mathrm{x}}$ and $\mathrm{NO}_{\mathrm{x}}$ emissions of the German domain are presented in Fig. 1. The distributions illustrate that emission regimes vary significantly. Agricultural ammonia-rich 

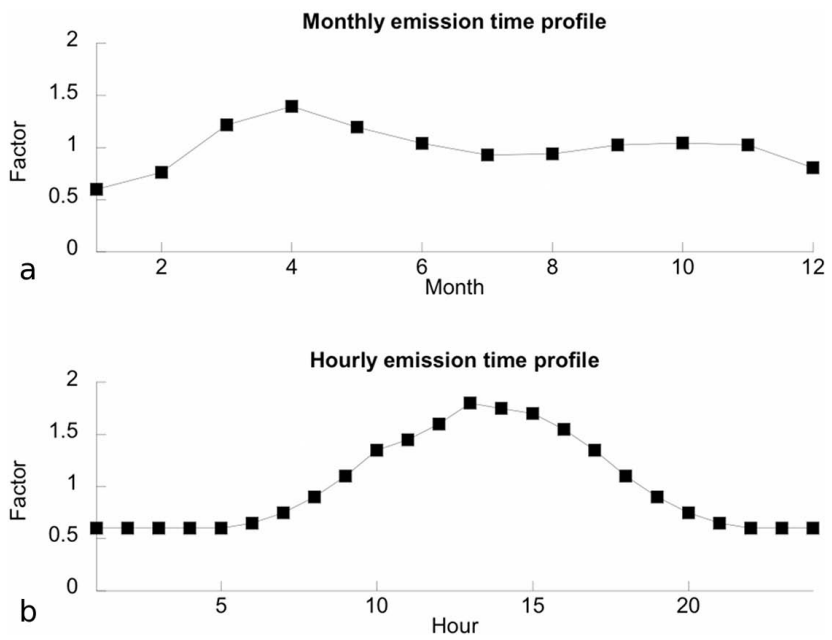

Fig. 2. Profiles of (a) monthly and (b) hourly ammonia emission factors applied in RCG.

areas are situated in the northwest and southeast of the domain. The $\mathrm{SO}_{\mathrm{x}}$ emissions are located in the industrial areas whereas $\mathrm{NO}_{\mathrm{x}}$ emissions are highest in urbanised regions and transport corridors. The temporal variation of the emissions is represented by monthly, day-of-the-week and hourly time factors for each source category. These factors were taken from the EURODELTA database (Thunis et al., 2008). The applied monthly and hourly time factors for ammonia are shown in Fig. 2. The seasonal variation in ammonia emissions is uncertain and may differ regionally as a function of farming procedures and climatic conditions (Geels et al., 2012). The seasonal variation for Germany shows a distinct maximum in March/April due to the application of manure. The diurnal cycle in the emission follows the empirically derived distribution by Asman (2001) with half the average value at midnight and twice the average at noon.

\subsection{Model runs}

To investigate the mitigation potential of emission reductions of the precursor gases $\mathrm{SO}_{2}, \mathrm{NO}_{\mathrm{x}}$ and $\mathrm{NH}_{3}$ on SIA concentrations and $\mathrm{S}$ and $\mathrm{N}$ deposition fluxes, a base case simulation and model runs for three reduction scenarios have been performed:

1. reducing $\mathrm{NH}_{3}$ emissions only,

2. reducing $\mathrm{SO}_{2}$ and $\mathrm{NO}_{\mathrm{x}}$ emissions simultaneously, and

3. reducing $\mathrm{SO}_{2}, \mathrm{NO}_{\mathrm{x}}$ and $\mathrm{NH}_{3}$ simultaneously.

The emission reduction scenario runs are listed and labelled in Table 1. All model runs have been performed using modelled droplet $\mathrm{pH}$. To study the impact of national measures compared to European-wide mitigation efforts, all reduction scenario runs have been performed twice:
Table 2. Total annual German and German domain $\mathrm{SO}_{\mathrm{x}}, \mathrm{NO}_{\mathrm{x}}$ and $\mathrm{NH}_{3}$ emissions and the ratio of German emissions to German domain emissions.

\begin{tabular}{llll}
\hline Emissions & $\begin{array}{l}\mathrm{SO}_{\mathrm{x}} \\
\left(\mathrm{t} \mathrm{a}^{-1}\right)\end{array}$ & $\begin{array}{l}\mathrm{NO}_{\mathrm{x}} \\
\left(\mathrm{t} \mathrm{a}^{-1}\right)\end{array}$ & $\begin{array}{l}\mathrm{NH}_{3} \\
\left(\mathrm{t} \mathrm{a}^{-1}\right)\end{array}$ \\
\hline $\begin{array}{l}\text { German domain emissions } \\
\text { German emissions }\end{array}$ & $\begin{array}{l}979800 \\
561580\end{array}$ & $\begin{array}{l}2402052 \\
1543970\end{array}$ & $\begin{array}{l}876200 \\
606880\end{array}$ \\
$\begin{array}{l}\text { German emissions/ } \\
\text { German domain emissions }\end{array}$ & 0.57 & 0.64 & 0.69 \\
\hline
\end{tabular}

Table 3. Overview of performed ammonia emission sensitivity scenario runs and their set-up.

\begin{tabular}{lcccc}
\hline Scenario runs & $\begin{array}{c}\mathrm{pH} \\
\text { modelled }\end{array}$ & $\begin{array}{c}\mathrm{pH} \\
\text { constant }\end{array}$ & $\begin{array}{c}\text { German } \\
\text { domain (GD) }\end{array}$ & $\begin{array}{c}\text { European } \\
\text { domain (ED) }\end{array}$ \\
\hline$-60 \% \mathrm{NH}_{3}$ & $\mathrm{x}$ & $\mathrm{x}$ & $\mathrm{x}$ & - \\
$-40 \% \mathrm{NH}_{3}$ & $\mathrm{x}$ & $\mathrm{x}$ & $\mathrm{x}$ & $\mathrm{x}$ \\
$-20 \% \mathrm{NH}_{3}$ & $\mathrm{x}$ & $\mathrm{x}$ & $\mathrm{x}$ & - \\
base run & $\mathrm{x}$ & $\mathrm{x}$ & $\mathrm{x}$ & - \\
$+20 \% \mathrm{NH}_{3}$ & $\mathrm{x}$ & $\mathrm{x}$ & $\mathrm{x}$ & - \\
$+40 \% \mathrm{NH}_{3}$ & $\mathrm{x}$ & $\mathrm{x}$ & $\mathrm{x}$ & - \\
\hline
\end{tabular}

1. emissions have been reduced within the German domain only (scenario runs denoted by GD) and

2. emissions have been reduced within the German domain and within the European domain lowering the boundary conditions (scenario runs denoted by ED).

For simplicity, the emission reductions to assess national or regional measures were applied to the whole German zoom domain. Inevitably, this domain comprises parts of neighbouring countries and seas. As for the land area, around two thirds of the emissions in the GD domain are from Germany itself (see Table 2).

To study the model sensitivity to ammonia emission changes in more detail, additional model runs have been performed in which ammonia emissions have been varied on the German domain $20 \%$-stepwise from $-60 \%$ to $+40 \%$. The emission scenario runs are listed and labelled in Table 3. To study the sensitivity of the model results to the variable $\mathrm{pH}$ in cloud water, which has often been neglected in previous studies, the sensitivity runs have been performed twice:

1. applying modelled droplet $\mathrm{pH}$ and

2. applying a constant $\mathrm{pH}$ of 5.5.

Finally, to study the impact of long-range transport, the $-40 \% \mathrm{NH}_{3}$ emission scenario run has been performed on the German domain (scenario runs denoted by GD) and on the European domain implying emission reduction within the German and the boundary conditions (scenario runs denoted by ED). 


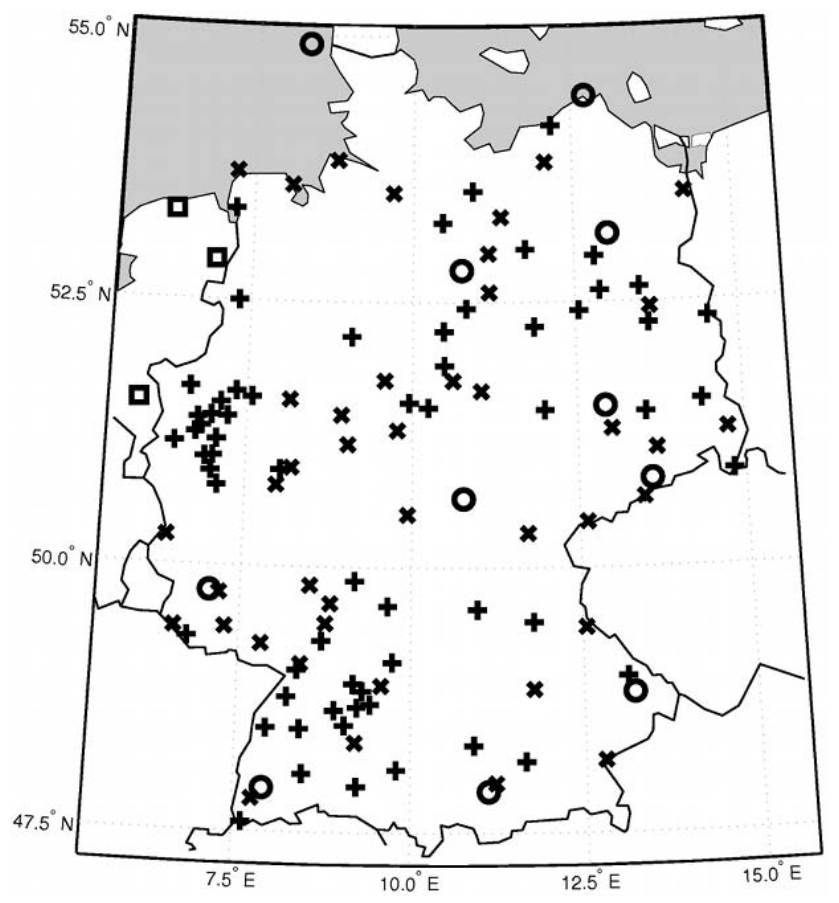

Fig. 3. Map of observational station locations: $\mathrm{PM}_{10}$ concentrations (rural background) (x), $\mathrm{PM}_{10}$ concentrations (suburban background) (+), SIA concentrations ( $\square$ ), wet deposition fluxes (o).

\subsection{Observations}

AirBase (European AIR quality database, http://airbase. eionet.europa.eu/) provides $\mathrm{PM}_{10}$ air concentrations for a large number of European measurement stations. For the evaluation of RCG, $\mathrm{PM}_{10}$ model results have been compared to daily averages of $\mathrm{PM}_{10}$ at 42 rural background stations in AirBase within Germany. A comparison to 63 suburban background stations in AirBase over Germany has also been included.

Data from the national German monitoring network (UBA, 2004) are used for evaluation of COSMO-EU precipitation and RCG wet deposition fluxes. Precipitation sampling is performed by using wet-only collectors (Firma Eigenbrodt, Germany). Weekly total precipitation and wet deposition fluxes for 11 stations within Germany were available. At the time of writing no quality-controlled SIA measurement data for Germany were available. Measurement data of sulfate, nitrate and ammonium for three observational sites (Vredepeel, Kollumerwaard, Valthermond) close to the German border were supplied by the Dutch National Institute for Public Health and the Environment (www.rivm.nl). The locations of all stations are shown in Fig. 3.

\section{Investigation period}

\subsection{Meteorological conditions}

The investigation period was 24 March to 28 April in spring 2009. According to the German Weather Service, the mean temperature over central Europe in spring 2009 was up to $3 \mathrm{~K}$ higher than the mean of the reference period of 30 years (1961-1990). In April this temperature anomaly was even more than $4 \mathrm{~K}$. This extremely warm, dry and sunny weather in April 2009 was related to high-pressure systems with rather stable air conditions and little atmospheric mixing. In Germany, in April 2009 the mean temperature of $11.9^{\circ} \mathrm{C}$ was $4.5 \mathrm{~K}$ higher than the mean of the reference period. April 2009 was announced as the warmest April since the beginning of comprehensive weather observations 120 years ago. Sunshine duration was $62 \%$ above average while, regionally, precipitation amounts were far below average. For example, at station Berlin-Buch only $1 \mathrm{~mm}$ of precipitation was observed in April. The weather conditions were especially dry and sunny for north eastern Germany, north western Poland and the northern part of the Czech Republic, with monthly mean cloud fractions of $20-40 \%$, whereas the climatological mean (1971-2000) of cloud fraction over central Europe amounts to $60-75 \%$ for April. Mean cloud fraction in central and eastern Germany and western Czech Republic was, with $40-50 \%$, also below the climatological mean while in western and southwestern Germany, the Netherlands, Belgium, France and Great Britain the mean cloud fraction was above $60 \%$.

\section{2 $\mathrm{PM}_{10}$ concentrations}

Stable air conditions lead to high $\mathrm{PM}_{10}$ levels (Mues et al., 2012; Demuzere et al., 2009). For April 2009 the average $\mathrm{PM}_{10}$ concentration over German rural background stations operated by UBA was $25 \%$ higher than the average over the previous 9 years (2000-2008) (UBA, 2010). The EU limit for daily mean $\mathrm{PM}_{10}\left(24 \mathrm{~h}\right.$ average above $\left.50 \mu \mathrm{g} \mathrm{m}^{-3}\right)$ was exceeded between 9 and 12 days in this month at most stations in Belgium and the Netherlands and at several stations in Germany. There were two main high $\mathrm{PM}_{10}$ episodes within the investigation period: one from about 2 to 7 April and one from about 11 to 16 April. Figure 4 shows the daily mean $\mathrm{PM}_{10}$ concentration distribution over Germany derived by Optimal Interpolation of observations for the peak days of each episode. $\mathrm{PM}_{10}$ daily mean concentrations above $100 \mu \mathrm{g} \mathrm{m}^{-3}$ were measured at several stations in central $\mathrm{Eu}-$ rope within both episodes. On 13 April, daily mean $\mathrm{PM}_{10}$ concentrations of around $150 \mu \mathrm{g} \mathrm{m}^{-3}$ were measured at rural background stations in North Rhine-Westphalia in the west of Germany. In both episodes the fraction of SIA was very high, with measured daily mean SIA concentrations of up to above $70 \mu \mathrm{g} \mathrm{m}^{-3}$. In this study, the extremely high concentration levels and their origin during these episodes 

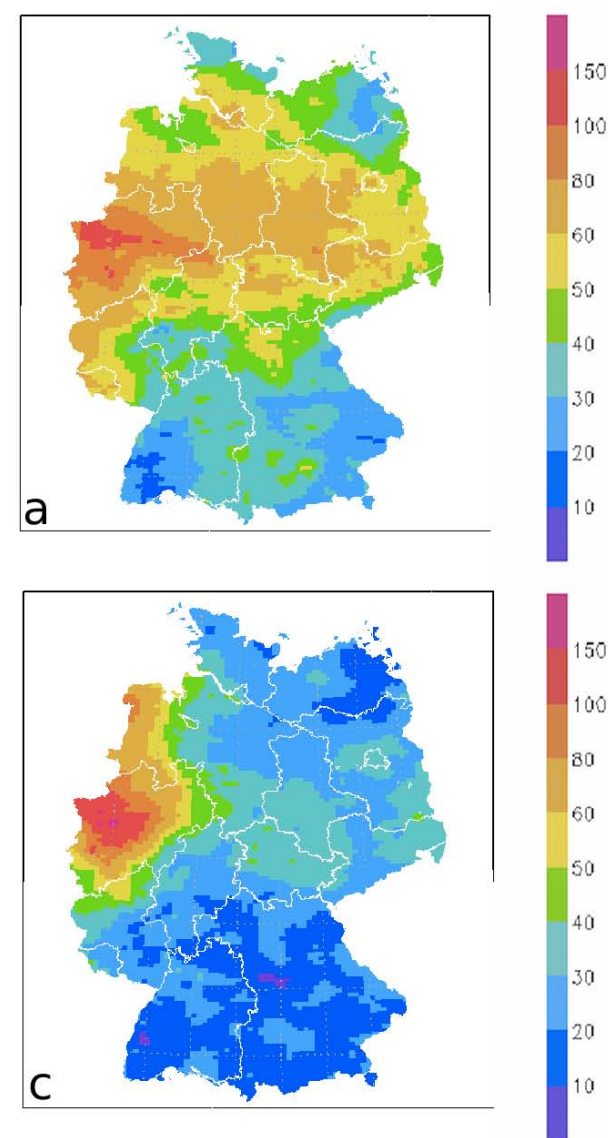
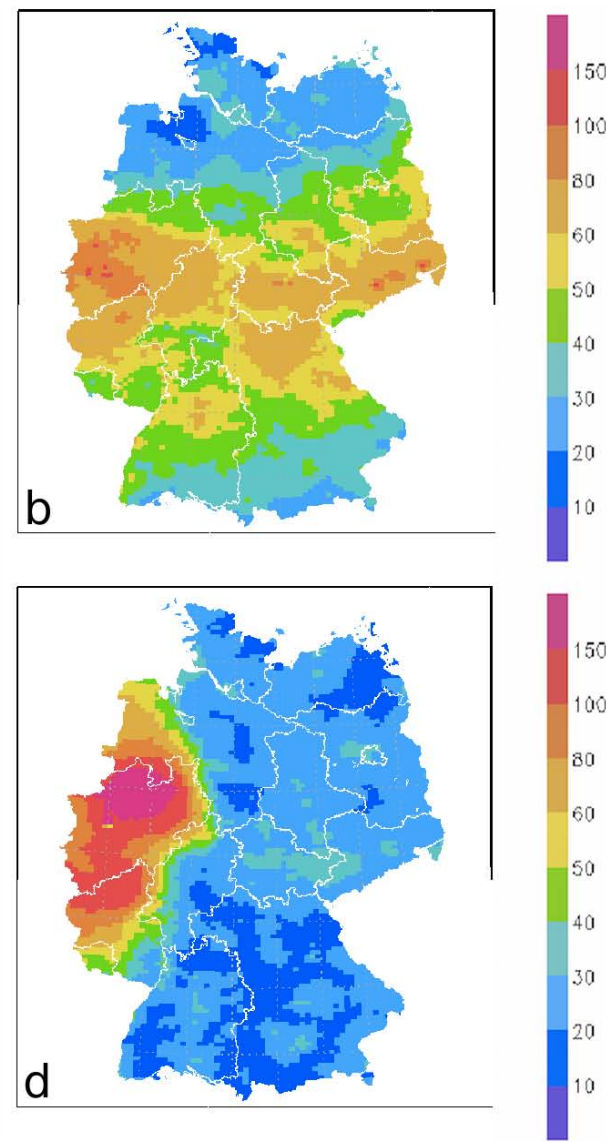

Fig. 4. Daily mean $\mathrm{PM}_{10}$ concentrations in $\mu \mathrm{g} \mathrm{m} \mathrm{m}^{-3}$ on (a) 4 and (b) 5 April 2009 and (c) 12 and (d) 13 April 2009 derived by Optimal Interpolation of observations.

are investigated, which is highly relevant for mitigation purposes.

\section{Results}

\subsection{Model performance}

Figure 5a shows a scatter plot of the modelled daily mean $\mathrm{PM}_{10}$ concentrations of the base run compared to observations at 42 rural background stations within Germany. The corresponding statistics are given in Table 4. The model performs well with a correlation of 0.75 . The model tends to overestimate low $\mathrm{PM}_{10}$ values and underestimate the high peaks. The bias of $+2.95 \mu \mathrm{g} \mathrm{m}^{-3}$ (observed mean $22.56 \mu \mathrm{g} \mathrm{m}^{-3}$ ) indicates a slight overall overestimation by the model. A comparison of modelled $\mathrm{PM}_{10}$ concentrations to 63 suburban background stations (not shown here) reveals a similar correlation coefficient of 0.71 . The observed daily mean $\mathrm{PM}_{10}$ concentrations are with $27.01 \mu \mathrm{g} \mathrm{m}^{-3}$ higher than for the rural background stations. Also the RMSE is higher than for rural background stations, which is partly related to a higher frequency of peak values. Figure $5 \mathrm{~b}$ shows the time series of $\mathrm{PM}_{10}$ daily means at station WesterwaldHerdorf. The model nicely reproduces the temporal variation of $\mathrm{PM}_{10}$ concentrations throughout the investigation period. However, as already recognised in the scatter plot, the model tends to underestimate peak values and overestimate low values.

Figure 6a shows modelled daily mean SIA concentrations compared to measurements at 3 Dutch observational sites. The model performs well with a correlation coefficient of 0.76 . The bias of $-2.10 \mu \mathrm{g} \mathrm{m}^{-3}$ indicates a slight overall underestimation of SIA concentrations by the model. Similar to the $\mathrm{PM}_{10}$ concentrations, the SIA concentrations in the high concentration range are underestimated by the model.

In Fig. 6b, time series of the SIA components $\mathrm{SO}_{4}^{2-}, \mathrm{NO}_{3}^{-}$ and $\mathrm{NH}_{4}^{+}$at station Kollumerwaard (NL) are presented. The high correlation coefficients for $\mathrm{SO}_{4}^{2-}, \mathrm{NO}_{3}^{-}$and $\mathrm{NH}_{4}^{+}$in Table 4 indicate that the model captures the temporal variability of SIA concentrations well. The model tends to overestimate $\mathrm{SO}_{4}^{2-}$ concentrations and underestimate $\mathrm{NO}_{3}^{-}$concentrations while $\mathrm{NH}_{4}^{+}$concentrations are simulated well for the considered period. The correlations for the precursor gases $\mathrm{SO}_{2}$ and $\mathrm{NO}_{2}\left(\mathrm{NH}_{3}\right.$ concentration measurements were unfortunately 

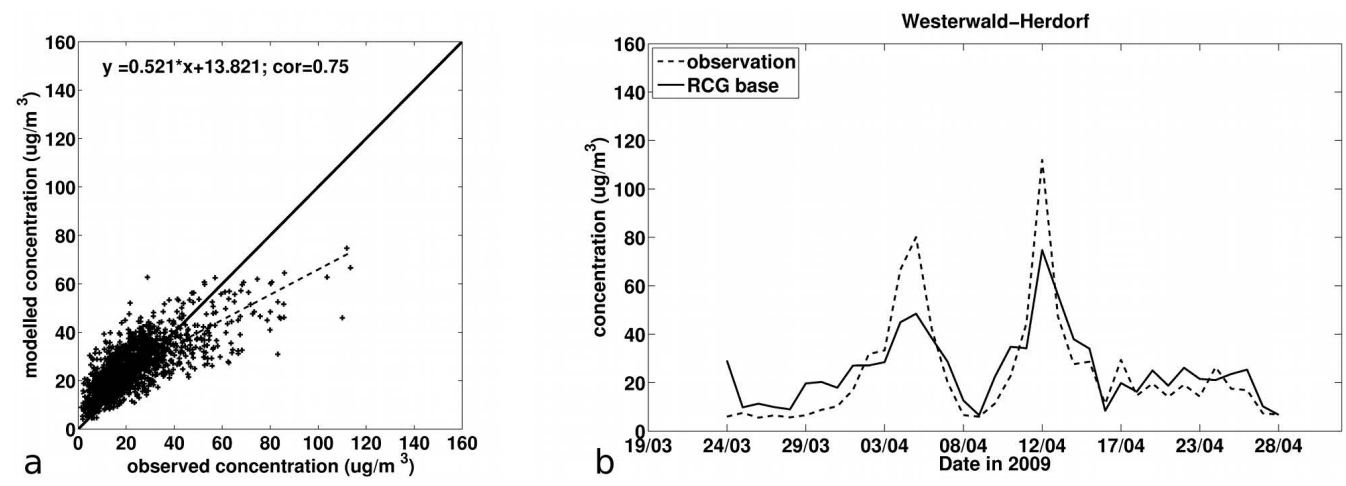

Fig. 5. Daily mean modelled $\mathrm{PM}_{10}$ concentrations (a) versus observations at 42 AirBase sites and (b) versus observations at AirBase site Westerwald-Herdorf.
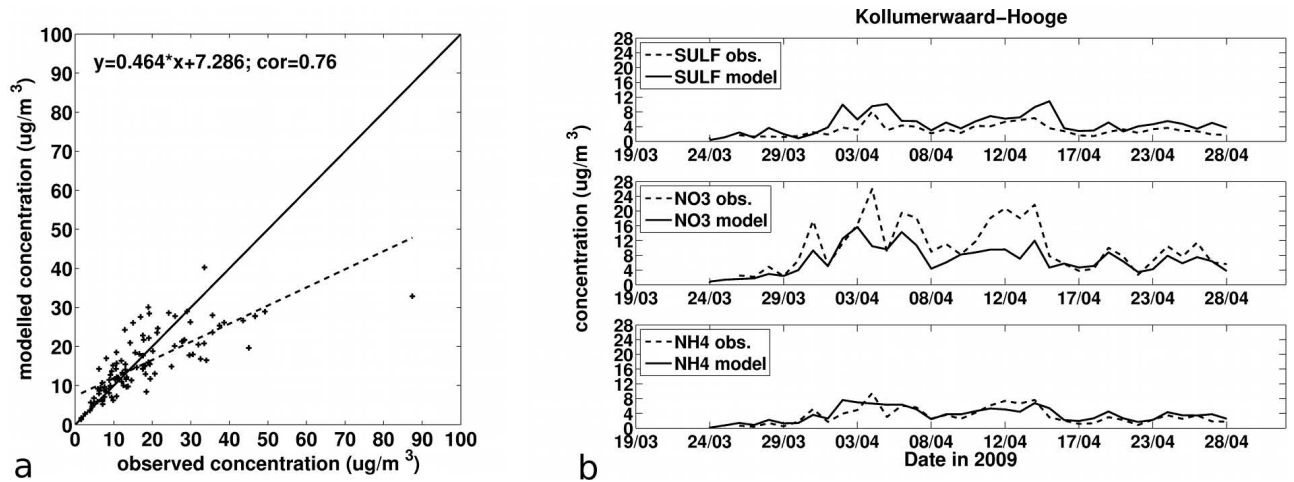

Fig. 6. Daily mean modelled SIA concentrations (a) versus observations at 3 RIVM sites and (b) versus observations at station Kollumerwaard.

not available for Germany in 2009) show that RCG is able to capture the temporal variability of the analysed species concentrations. Surface $\mathrm{SO}_{2}$ concentrations tend to be overestimated by RCG, while $\mathrm{NO}_{2}$ concentrations tend to be underestimated.

Total wet deposition fluxes of $\mathrm{SO}_{\mathrm{x}}, \mathrm{NO}_{\mathrm{y}}$ and $\mathrm{NH}_{\mathrm{x}}$ for the investigation period are compared to observations at $11 \mathrm{UBA}$ sites within Germany. The model performance concerning wet deposition fluxes is summarised in Fig. 7. The corresponding statistics are given in Table 4 . The spatial correlations between model results and observations are high, with values of $0.82,0.80$ and 0.74 for $\mathrm{SO}_{\mathrm{x}}, \mathrm{NO}_{\mathrm{y}}$ and $\mathrm{NH}_{\mathrm{x}}$, respectively. The bias indicates that $\mathrm{SO}_{\mathrm{x}}$ and $\mathrm{NH}_{\mathrm{x}}$ wet deposition fluxes are underestimated by the model while $\mathrm{NO}_{\mathrm{y}}$ is slightly overestimated. Figure $7 \mathrm{~d}$ shows the comparison of COSMO-EU precipitation to observations at the 11 wet deposition measurement sites. The spatial correlation is 0.57 .

Although some shortcomings can be identified, the overall performance is satisfactory and in line with or better than in previous studies (e.g. Stern et al., 2008; Solazzo et al., 2012). The model is able to capture the main variability of the components' concentrations and deposition fluxes in space and time.

\subsection{Origin and characteristics of the $\mathrm{PM}_{10}$ episodes in spring 2009}

The model evaluation in Sect. 4.1 has shown that RCG performs well in simulating the temporal and spatial variation of SIA and $\mathrm{PM}_{10}$ concentrations within the investigation period. Thus, RCG is used to investigate origin and characteristics of the high $\mathrm{PM}_{10}$ episodes in spring 2009.

\subsubsection{First episode (2 April 2009-7 April 2009)}

From the end of March, a high-pressure system over northern central Europe determined the weather pattern over the investigation area. In northern France and northern Netherlands the stagnant air conditions led to the accumulation of SIA precursor gases, enhancing local SIA formation in the beginning of April. SIA was dominated by ammonium-nitrate due to elevated $\mathrm{NO}_{\mathrm{x}}$ levels originating from road transport and shipping activities, combined with high $\mathrm{NH}_{3}$ emission levels originating from local agricultural activity. On 3 April a ridge over the Atlantic sea west of France induced clouds over northern and central France. The cloud cover was 50-100\%. On 4 April, a trough passed the British Islands and moved westwards transporting the polluted air masses, containing 
Table 4. Statistical comparison between measured and modelled concentrations and wet deposition fluxes at different stations (see Fig. 3) for the investigation period. Observed mean, as well as BIAS, RMSE and correlation are given.

\begin{tabular}{|c|c|c|c|c|}
\hline Concentrations and wet deposition fluxes & Observed mean & RMSE & BIAS & Correlation \\
\hline $\mathrm{PM}_{10}$ concentration (rural background) & $22.56 \mu \mathrm{g} \mathrm{m}^{-3}$ & $10.36 \mu \mathrm{g} \mathrm{m}^{-3}$ & $2.95 \mu \mathrm{g} \mathrm{m}^{-3}$ & 0.75 \\
\hline $\mathrm{PM}_{10}$ concentration (suburban background) & $27.01 \mu \mathrm{g} \mathrm{m}^{-3}$ & $12.61 \mu \mathrm{g} \mathrm{m}^{-3}$ & $1.28 \mu \mathrm{g} \mathrm{m}^{-3}$ & 0.71 \\
\hline SIA concentration (rural background) & $17.55 \mu \mathrm{g} \mathrm{m}^{-3}$ & $8.88 \mu \mathrm{g} \mathrm{m}^{-3}$ & $-2.10 \mu \mathrm{g} \mathrm{m}^{-3}$ & 0.76 \\
\hline $\mathrm{SO}_{4}^{2-}$ concentration (rural background) & $3.4 \mu \mathrm{g} \mathrm{m}^{-3}$ & $2.6 \mu \mathrm{g} \mathrm{m}^{-3}$ & $1.3 \mu \mathrm{g} \mathrm{m}^{-3}$ & 0.63 \\
\hline $\mathrm{NO}_{3}^{-}$concentration (rural background) & $11.7 \mu \mathrm{g} \mathrm{m}^{-3}$ & $6.3 \mu \mathrm{g} \mathrm{m}^{-3}$ & $-3.5 \mu \mathrm{g} \mathrm{m}^{-3}$ & 0.76 \\
\hline $\mathrm{NH}_{4}^{+}$concentration (rural background) & $4.1 \mu \mathrm{g} \mathrm{m}^{-3}$ & $2.16 \mu \mathrm{g} \mathrm{m}^{-3}$ & $0.17 \mu \mathrm{g} \mathrm{m}^{-3}$ & 0.73 \\
\hline $\mathrm{SO}_{2}$ concentration (rural/suburban background) & $3.9 \mu \mathrm{g} \mathrm{m}^{-3}$ & $5.4 \mu \mathrm{g} \mathrm{m}^{-3}$ & $2.9 \mu \mathrm{g} \mathrm{m}^{-3}$ & 0.62 \\
\hline $\mathrm{NO}_{2}$ concentration (rural/suburban background) & $15.0 \mu \mathrm{g} \mathrm{m}^{-3}$ & $8.8 \mu \mathrm{g} \mathrm{m}^{-3}$ & $-4.5 \mu \mathrm{g} \mathrm{m}^{-3}$ & 0.65 \\
\hline $\mathrm{SO}_{\mathrm{x}}$ wet deposition & $102.27 \mathrm{mg} \mathrm{m}^{-2}$ & $45.9 \mathrm{mg} \mathrm{m}^{-2}$ & $-32.2 \mathrm{mg} \mathrm{m}^{-2}$ & 0.82 \\
\hline $\mathrm{NO}_{\mathrm{y}}$ wet deposition & $50.10 \mathrm{mg} \mathrm{m}^{-2}$ & $19.2 \mathrm{mg} \mathrm{m}^{-2}$ & $7.3 \mathrm{mg} \mathrm{m}^{-2}$ & 0.80 \\
\hline $\mathrm{NH}_{\mathrm{X}}$ wet deposition & $40.91 \mathrm{mg} \mathrm{m}^{-2}$ & $23.4 \mathrm{mg} \mathrm{m}^{-2}$ & $-11.6 \mathrm{mg} \mathrm{m}^{-2}$ & 0.74 \\
\hline Precipitation & $50.75 \mathrm{~mm}$ & $29.4 \mathrm{~mm}$ & $2.5 \mathrm{~mm}$ & 0.57 \\
\hline
\end{tabular}
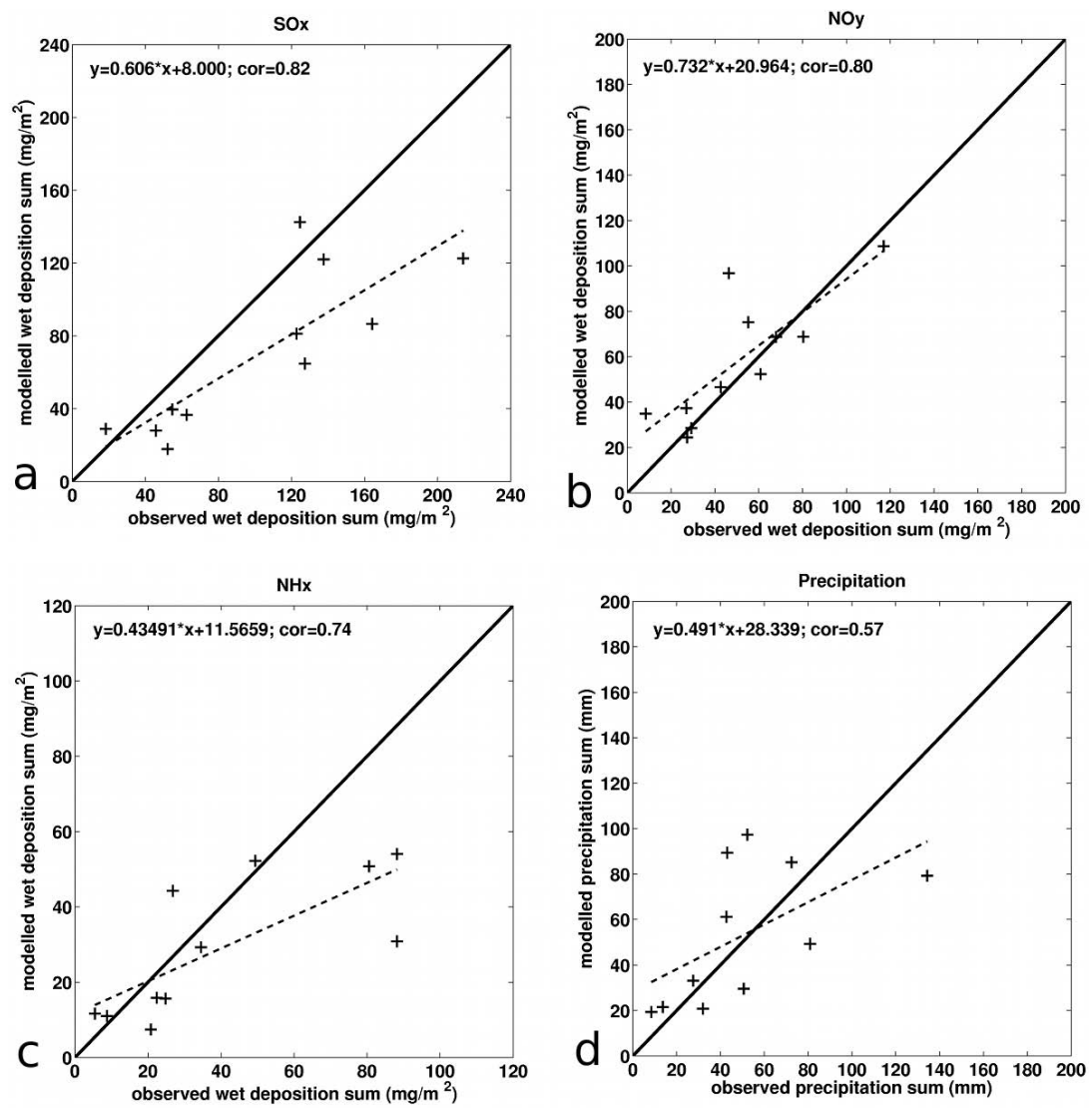

Fig. 7. Modelled wet deposition sum of (a) $\mathrm{SO}_{x}$, (b) $\mathrm{NO}_{y}$, (c) $\mathrm{NH}_{\mathrm{x}}$ and (d) total precipitation for the investigation period versus observations at 11 UBA sites.

high SIA and high $\mathrm{NO}_{\mathrm{x}}$ concentrations, towards Germany. Passing ammonia-rich areas, further ammonium-nitrate formation occurred within the humid air mass. The polluted air mass reached Germany in the late morning hours of 4 April and spread out over the country in the following hours. On
4 April, by the time of the arrival of the polluted air mass, the cloud cover across Germany was largely between 70$100 \%$. Figure 8 a shows modelled average SIA concentrations of the base run for 4 April. Average SIA concentrations exceeded $45 \mu \mathrm{g} \mathrm{m}^{-3}$ that day. We would like to stress 

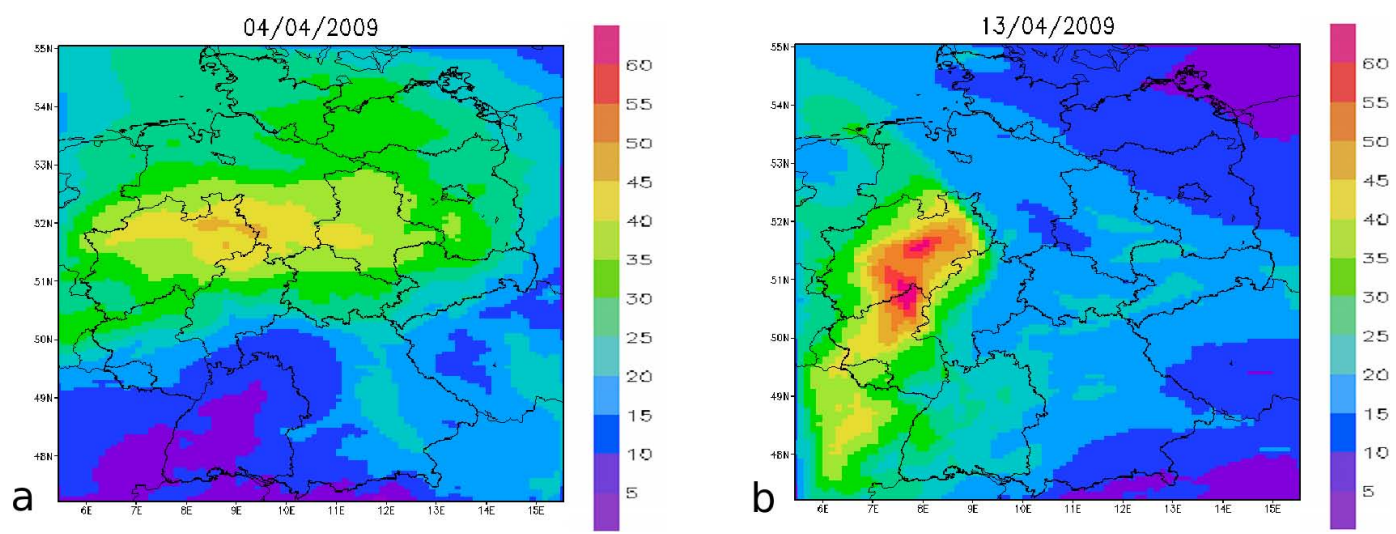

Fig. 8. Modelled mean SIA concentration of the base run for (a) 4 April 2009 and (b) 13 April 2009.

that the spatial distribution of modelled SIA concentrations in Fig. 8a compares well to the spatial distribution of observed $\mathrm{PM}_{10}$ concentrations on 4 April shown in Fig. 4a. On 5 April a high-pressure system built up over northern Germany. The stagnant air conditions led to the accumulation of pollutants that had been transported to Germany (mainly SIA and precursor $\mathrm{NO}_{\mathrm{x}}$ ) during 4 April and local emitted pollutants. As a result, the SIA originating from local formation in Germany on 5 April added up to the SIA originating from long-range transport. Modelled hourly SIA concentrations exceeded $70 \mu \mathrm{g} \mathrm{m}^{-3}$ on 5 April.

\subsubsection{Second episode (11-16 April 2009)}

From 11 to 16 April a ridge over central Europe led to warm weather and stagnant air conditions over Germany. The latter resulted in pollutant accumulation and enhanced local SIA formation over western Germany due to high precursor emissions in the Ruhr area and its surrounding. On 13 and 14 April western Germany was situated on the very western border of the ridge with very stagnant conditions favouring the build-up and local formation of SIA and precursor levels. While large parts of northeastern and southeastern Germany were cloud-free, in the west and southwestern Germany the cloud cover was $40-100 \%$. The latter was also the case for large parts of Belgium and northern France. Different from the first episode, ammonium-sulfate and ammonium-nitrate levels were equally high. The model simulations show that ammonium-sulfate was mainly formed during the daytime when temperatures were high (above $25^{\circ} \mathrm{C}$ ) while ammonium-nitrate was mainly formed during the nighttime and early morning hours at moderate temperatures $\left(10-15^{\circ} \mathrm{C}\right)$ and high relative humidity $(80-90 \%)$. Figure $8 \mathrm{~b}$ shows modelled average SIA concentrations for 13 April. In North Rhine-Westphalia, in the west of Germany, average SIA concentrations exceeded a daily average of $60 \mu \mathrm{g} \mathrm{m}^{-3}$. Again, the spatial distribution of modelled SIA concentrations in Fig. 8b compares well to the spatial distri- bution of observed $\mathrm{PM}_{10}$ concentrations on 13 April shown in Fig. 4d.

The analysis using RCG shows that the high SIA concentrations are of different origin for the two episodes. Within the first episode, SIA was mainly formed outside of Germany while within the second episode, SIA mainly originated from local sources within Germany. This will be further discussed in Sect. 5.

\subsection{Emission scenarios}

\subsubsection{Sensitivity of SIA concentrations to ammonia emission changes}

Figure 9 presents a time series of daily mean sulfate, nitrate and ammonium concentrations at station WesterwaldHerdorf. The station location is marked ( $\mathrm{x}$ ) on the map on the upper right-hand side. The station is located in the western part of Germany and was affected by both episodes. Figure 9 includes 3 different runs: base run, $-40 \% \mathrm{NH}_{3}$ GD run and $+40 \% \mathrm{NH}_{3} \mathrm{GD}$ run. The figure again illustrates that the first episode around 4 April was dominated by ammonium-nitrate while during the second episode around 12 April ammoniumsulfate and ammonium-nitrate levels were equally high.

All SIA components clearly show a dependency on ammonia emission changes: mean concentrations increase compared to the base run when ammonia emissions are increased and vice versa. Sulfate concentrations are sensitive to changes in ammonia emission as ammonia affects droplet $\mathrm{pH}$ and consequently the rate of sulfate formation. Also, changes in ammonia emissions affect the availability of "free ammonia" and therewith affect the amount of ammoniumnitrate formation. The comparison of Fig. 9a and b shows that changes in ammonia emissions affect nitrate concentrations to a higher extent than sulfate concentrations. Relative to the base run, nitrate concentrations increase by up to $42 \%$ for the $+40 \% \mathrm{NH}_{3} \mathrm{GD}$ run and decrease by up to $60 \%$ for the $-40 \% \mathrm{NH}_{3} \mathrm{GD}$ run during the $\mathrm{PM}_{10}$ episodes. 


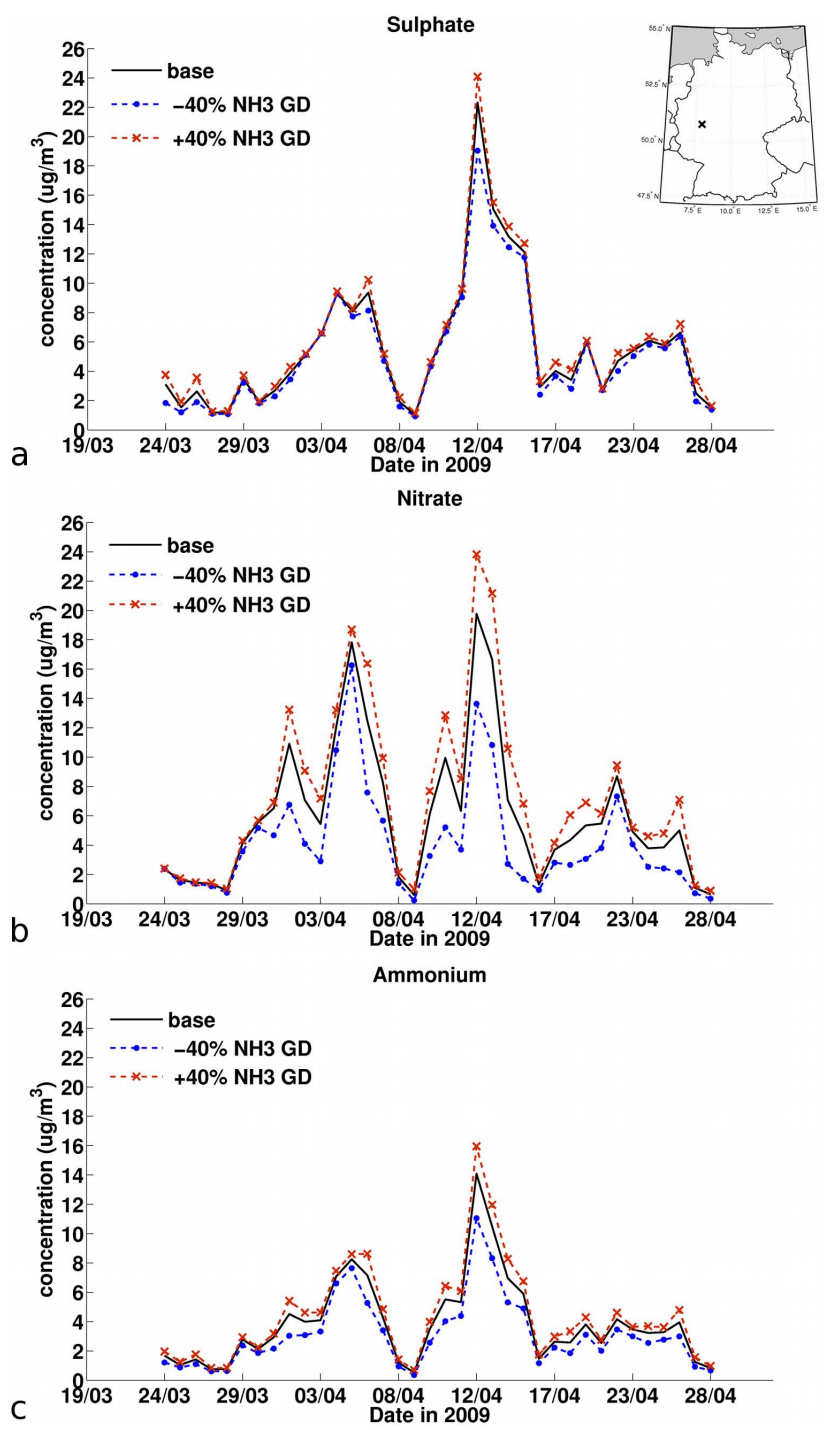

Fig. 9. Daily mean (a) sulfate, (b) nitrate and (c) ammonium concentration at station Westerwald-Herdorf for different ammonia emission scenario runs.

The sensitivity of SIA concentrations to ammonia emission changes for the German domain (GD) scenario runs is small on 4 and 5 April, but much larger on 12 and 13 April. These different sensitivities illustrate the importance of transport for the first episode and the local built up for the second episode. The non-linearity observed in the responses is further addressed below.

\subsubsection{Reduction scenarios}

The impact of 3 different emission reduction scenarios for 2 domains (GD and ED) on the mean modelled SIA concentration and total deposition flux in the German domain is presented in Fig. 10. Concentrations and deposition fluxes are averaged over the investigation period from 24 March to 28
April. The change in average SIA concentration and deposition fluxes compared to the base run refers to averages over the German domain. The corresponding relative changes in concentration and deposition flux are presented in Tables 5 and 6 , respectively. Figure 10a and $\mathrm{b}$ shows the results for emission reductions in the German domain and Fig. 10c and $\mathrm{d}$ shows the results for emission reductions in the European domain. The plots on the left-hand side show the SIA concentrations and the plots on the right-hand side the total deposition fluxes.

\section{GD emission reduction impact on SIA concentrations and total deposition fluxes}

Figure 10a shows that the air concentrations of particulate sulfate, nitrate and ammonium decrease for all performed emission reduction scenario runs compared to the base run. The mean SIA concentrations are reduced by $-4.6 \%$, $-12.6 \%$ and $-15.8 \%$ within the $-\mathrm{NO}_{\mathrm{x}}-\mathrm{SO}_{2} \mathrm{GD},-\mathrm{NH}_{3} \mathrm{GD}$ and $-\mathrm{NH}_{3}-\mathrm{NO}_{\mathrm{x}}-\mathrm{SO}_{2} \mathrm{GD}$ scenario run, respectively. This indicates a non-linear behaviour considering the corresponding precursor reductions. Sulfate concentrations are reduced by $-0.26 \mu \mathrm{g} \mathrm{m}^{-3}(-5.7 \%)$ and $-0.27 \mu \mathrm{g} \mathrm{m}^{-3}(-5.9 \%)$, within the $-\mathrm{NO}_{\mathrm{x}}-\mathrm{SO}_{2 \mathrm{GD}}$ and the $-\mathrm{NH}_{3} \mathrm{GD}$ scenario run, respectively. The $-\mathrm{NH}_{3}-\mathrm{NO}_{\mathrm{x}}-\mathrm{SO}_{2} \mathrm{GD}$ scenario run leads to a reduction of $-0.48 \mu \mathrm{g} \mathrm{m}^{-3}(-10.5 \%)$ in sulfate concentrations. This is less reduction in sulfate concentrations than the sum of sulfate concentration reductions of the scenario runs $-\mathrm{NO}_{\mathrm{x}}-\mathrm{SO}_{2} \mathrm{GD}$ and $-\mathrm{NH}_{3} \mathrm{GD}$. Nitrate is only slightly reduced within the $-\mathrm{NO}_{\mathrm{x}}-\mathrm{SO}_{2}$ GD scenario run $\left(-0.19 \mu \mathrm{g} \mathrm{m}^{-3}\right)$ but is significantly reduced within the $-\mathrm{NH}_{3 \mathrm{GD}}$ scenario run $\left(-0.91 \mu \mathrm{g} \mathrm{m}^{-3}\right)$. With a reduction of $-1.0 \mu \mathrm{g} \mathrm{m}^{-3}$ the reduction in nitrate concentrations within the $-\mathrm{NH}_{3}-\mathrm{NO}_{\mathrm{x}}-\mathrm{SO}_{2} \mathrm{GD}$ scenario run is also less than the sum of nitrate concentration reductions of the scenario runs $-\mathrm{NO}_{\mathrm{x}}-\mathrm{SO}_{2 \mathrm{GD}}$ and $\mathrm{NH}_{3} \mathrm{GD}$. The latter non-linearity can also be observed for ammonium concentrations, with reductions of $-0.14 \mu \mathrm{g} \mathrm{m}^{-3}$, $-0.41 \mu \mathrm{g} \mathrm{m}^{-3}$ and $0.50 \mu \mathrm{g} \mathrm{m}^{-3}$ for the $-\mathrm{NO}_{\mathrm{x}}-\mathrm{SO}_{2} \mathrm{GD}$, $\mathrm{NH}_{3}$ GD and $-\mathrm{NH}_{3}-\mathrm{NO}_{\mathrm{x}}-\mathrm{SO}_{2} \mathrm{GD}$, respectively.

Figure $10 \mathrm{~b}$ shows that other than for SIA concentrations, the reduction scenario runs do not only result in reductions in deposition fluxes. Reduced nitrogen dry deposition fluxes are slightly increased compared to the base run when $\mathrm{NO}_{\mathrm{x}}$ and $\mathrm{SO}_{2}$ emissions are reduced. Due to the reduction of $\mathrm{SO}_{2}$ and $\mathrm{NO}_{\mathrm{x}}$, less ammonia is consumed for the neutralisation of nitrate and sulfate leading to a higher concentration, lower transport distances and thus higher deposition within the country. A similar effect is observed for oxidised nitrogen deposition when ammonia emissions are reduced. Within the $-\mathrm{NH}_{3} \mathrm{GD}$ scenario run the total deposition of oxidised nitrogen is increased by $11.9 \%$.

For the same scenario run, the reduced nitrogen total deposition is decreased by $-33.8 \%$. The $\mathrm{NH}_{3}$ emission reductions cause a decrease in ammonium nitrate formation, 

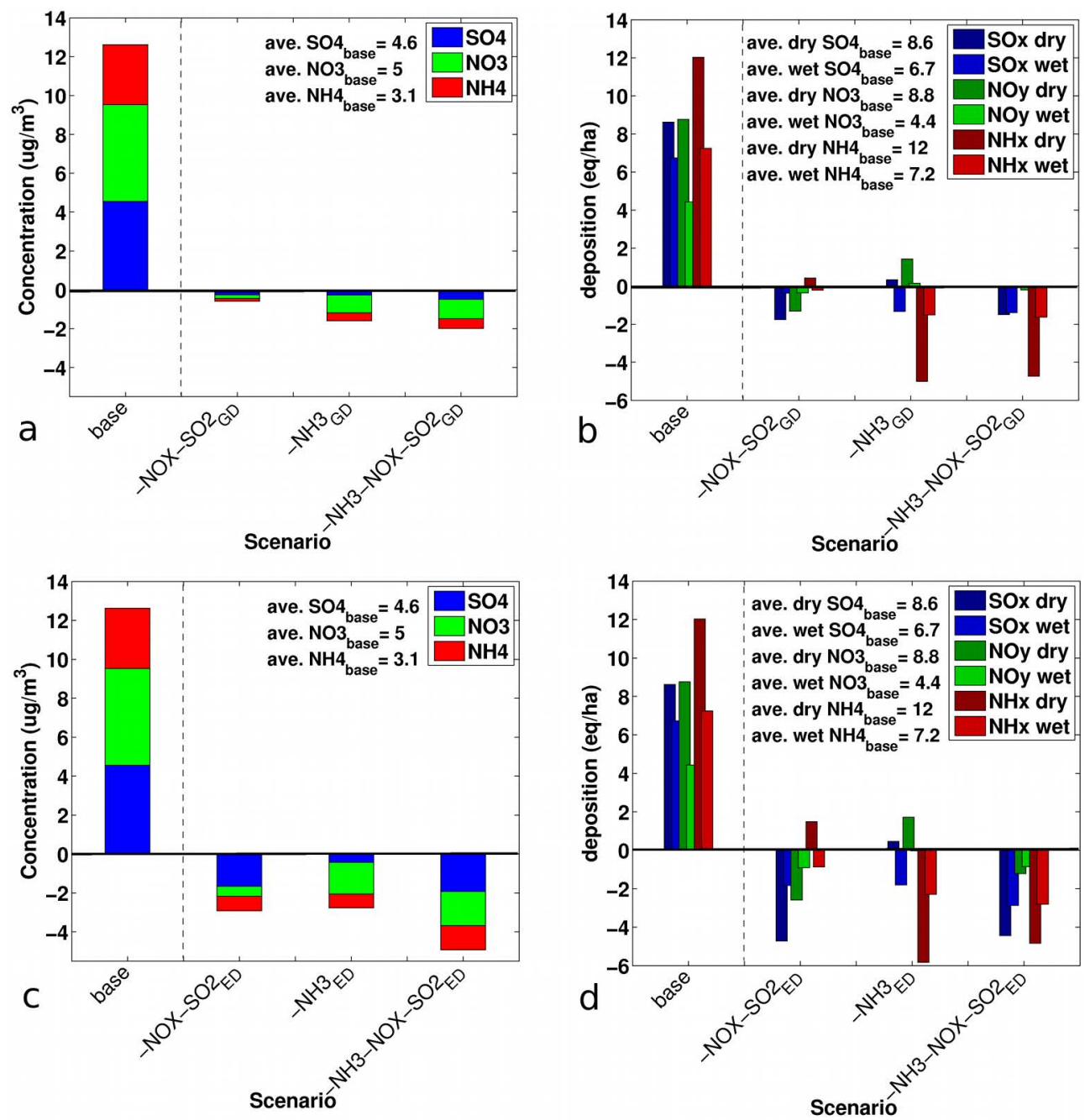

Fig. 10. Mean modelled (a) SIA concentration and (b) total deposition flux of the base run to the left of the dashed line and mean change in (a) SIA concentration and (b) total deposition flux for different emission scenario runs to the right of the dashed line. (a, b) show results for scenario runs on the German domain excluding the boundary conditions and (c, d) those on the German domain including the boundary conditions. The mean refers to the average over the investigation period from 24 March to 28 April.

Table 5. Relative change in concentration compared to the base run for total SIA, $\mathrm{SO}_{4}^{2-}, \mathrm{NO}_{3}^{-}$and $\mathrm{NH}_{4}^{+}$for the German domain emission scenario runs and the European domain emission scenario runs.

\begin{tabular}{lllllllll}
\hline \multirow{2}{*}{ Scenario run } & \multicolumn{9}{c}{ Change in concentration on $\mathrm{GD}(\%)$} & \multicolumn{5}{c}{ Change in concentration on ED (\%) } \\
\cline { 2 - 9 } & $\mathrm{SIA}$ & $\mathrm{SO}_{4}$ & $\mathrm{NO}_{3}$ & $\mathrm{NH}_{4}$ & $\mathrm{SIA}$ & $\mathrm{SO}_{4}$ & $\mathrm{NO}_{3}$ & $\mathrm{NH}_{4}$ \\
\hline$-\mathrm{NO}_{\mathrm{x}}-\mathrm{SO}_{2}$ & -4.6 & -5.7 & -3.8 & -4.5 & -23.1 & -36.4 & -10.2 & -22.5 \\
$-\mathrm{NH}_{3}$ & -12.6 & -5.9 & -18.3 & -13.2 & -21.9 & -9.4 & -32.7 & -22.9 \\
$-\mathrm{NH}_{3}-\mathrm{NO}_{\mathrm{x}}-\mathrm{SO}_{2}$ & -15.8 & -10.5 & -20.2 & -16.1 & -39.1 & -42.2 & -35.3 & -40.0 \\
\hline
\end{tabular}

which leads to higher $\mathrm{HNO}_{3}$ air concentrations and therewith to higher total deposition fluxes of oxidised nitrogen. As the deposition velocity of $\mathrm{HNO}_{3}$ is high, $\mathrm{HNO}_{3}$ dry deposition fluxes increase. As the decrease in reduced nitrogen is larger than the increase in oxidised nitrogen, the total $\mathrm{N}$ deposition is still reduced for the $-\mathrm{NH}_{3} \mathrm{GD}$ scenario run by $-15.2 \%$ while total deposition of $\mathrm{S}$ is reduced by $-6.5 \%$. For the $-\mathrm{NH}_{3}-\mathrm{NO}_{\mathrm{x}}-\mathrm{SO}_{2} \mathrm{GD}$ scenario run all components' wet and dry deposition fluxes are reduced (total deposition of $\mathrm{S}$ by $-18.9 \%$ and $\mathrm{N}$ by $-20.3 \%$ ). For the $-\mathrm{NO}_{\mathrm{x}}-\mathrm{SO}_{2} \mathrm{GD}$ scenario run the reduction of total $\mathrm{S}$ deposition amounts to $-13.9 \%$ and that of total $\mathrm{N}$ deposition 
Table 6. Relative change in deposition of $\mathrm{S}$ and $\mathrm{N}$ compared to the base run for the German domain scenario runs and the European domain scenario runs.

\begin{tabular}{lcccc}
\hline \multirow{2}{*}{ Scenario run } & \multicolumn{2}{c}{ Change in deposition on GD $(\%)$} & \multicolumn{2}{c}{ Change in deposition on ED (\%) } \\
\cline { 2 - 5 } & $\mathrm{S}$ & $\mathrm{N}$ & $\mathrm{S}$ & $\mathrm{N}$ \\
\hline$-\mathrm{NO}_{\mathrm{x}}-\mathrm{SO}_{2}$ & -13.9 & -4.4 & -42.6 & -8.8 \\
$-\mathrm{NH}_{3}$ & -6.5 & -15.2 & -8.7 & -19.8 \\
$-\mathrm{NH}_{3}-\mathrm{NO}_{\mathrm{x}}-\mathrm{SO}_{2}$ & -18.9 & -20.3 & -47.5 & -29.9 \\
\hline
\end{tabular}

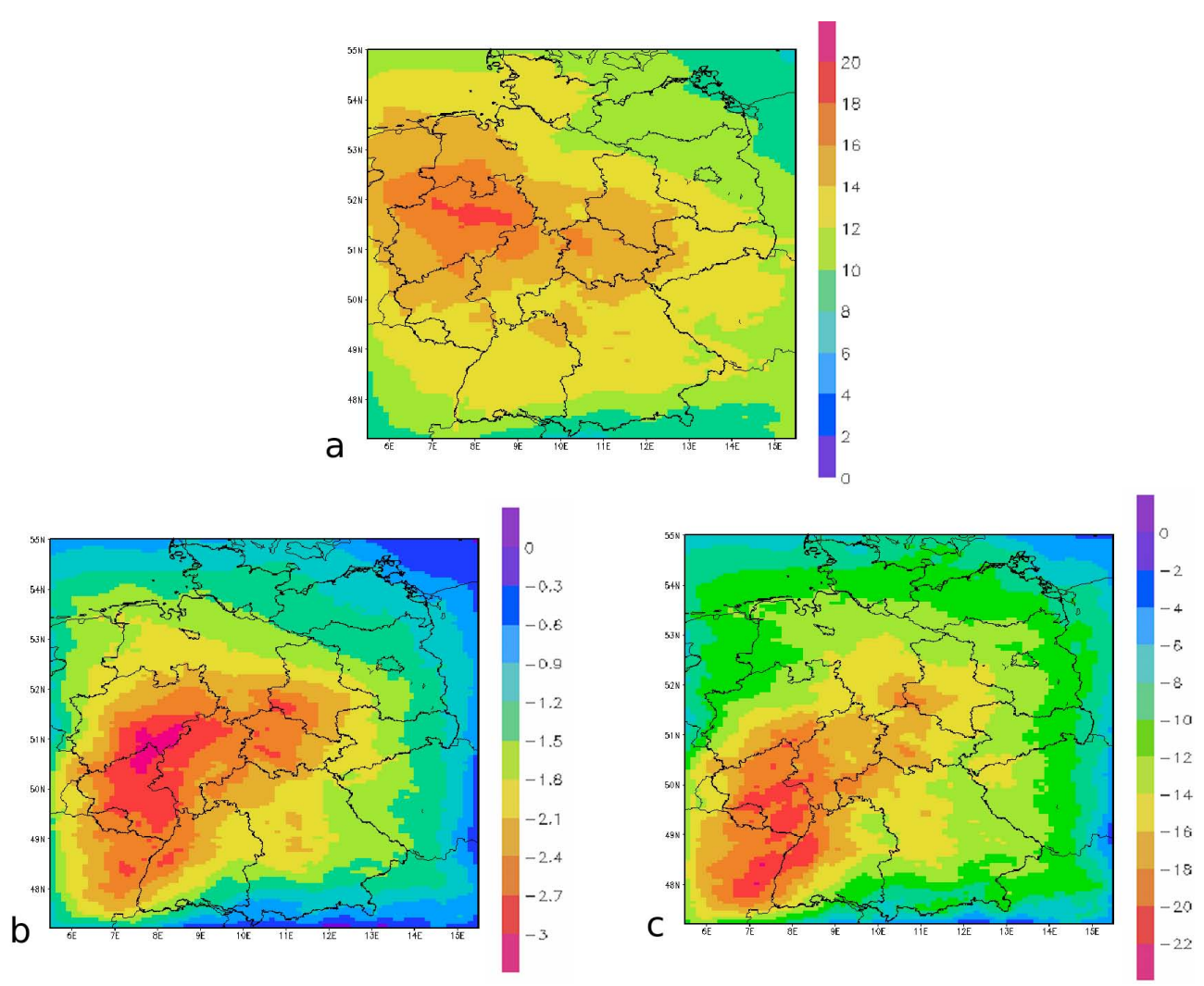

Fig. 11. (a) Base case mean SIA concentration $\left(\mu \mathrm{g} \mathrm{m}^{-3}\right)$ of the investigation period and (b) absolute and (c) relative SIA reduction by means of the $-40 \% \mathrm{NH}_{3}$ GD scenario run compared to the base case.

to $-4.4 \%$. Comparing the resultant deposition fluxes of the scenario runs $-\mathrm{NO}_{\mathrm{x}}-\mathrm{SO}_{2 \mathrm{GD}}$ and $-\mathrm{NH}_{3} \mathrm{GD}$ to those of scenario run $-\mathrm{NH}_{3}-\mathrm{NO}_{\mathrm{x}}-\mathrm{SO}_{2}$ GD shows that $\mathrm{S}$ and $\mathrm{N}$ deposition fluxes react more linearly on the emission changes than the SIA concentrations.

\section{German domain vs. European domain emission reductions}

Figure $10 \mathrm{c}$ and $\mathrm{d}$ shows the change in average German domain SIA concentrations and deposition fluxes resulting from the model runs for the different emission scenarios on the European domain. Concentrations of SIA are reduced by $-23.1 \%,-21.9 \%$ and $-39.1 \%$ for the $-\mathrm{NO}_{\mathrm{x}}-\mathrm{SO}_{2 \mathrm{ED}}$,
$-\mathrm{NH}_{3} \mathrm{ED}$ and $-\mathrm{NH}_{3}-\mathrm{NO}_{\mathrm{x}}-\mathrm{SO}_{2} \mathrm{ED}$ scenario run, respectively. The reduction in sulfate concentrations within the German domain changes significantly from GD to ED scenario run. The $-\mathrm{NH}_{3}-\mathrm{NO}_{\mathrm{x}}-\mathrm{SO}_{2} \mathrm{ED}$ scenario run is less effective in reducing SIA concentrations than the results of the scenario runs $-\mathrm{NO}_{\mathrm{x}}-\mathrm{SO}_{2} \mathrm{ED}$ and $-\mathrm{NH}_{3} \mathrm{ED}$ would suggest if linearity were assumed. The deviation from linearity is larger for the ED runs than for the GD runs in Fig. 10a. Among all reduction scenario runs the $-\mathrm{NH}_{3} \mathrm{GD} / \mathrm{ED}$ scenario runs show the least relative and absolute differences between GD and ED simulations.

The latter is also valid for the deposition fluxes. The $-\mathrm{NH}_{3} \mathrm{GD} / \mathrm{ED}$ scenario runs show the least differences between the GD and ED runs. The deviation from linearity is larger for the ED runs than for the GD runs. For the deposition fluxes 

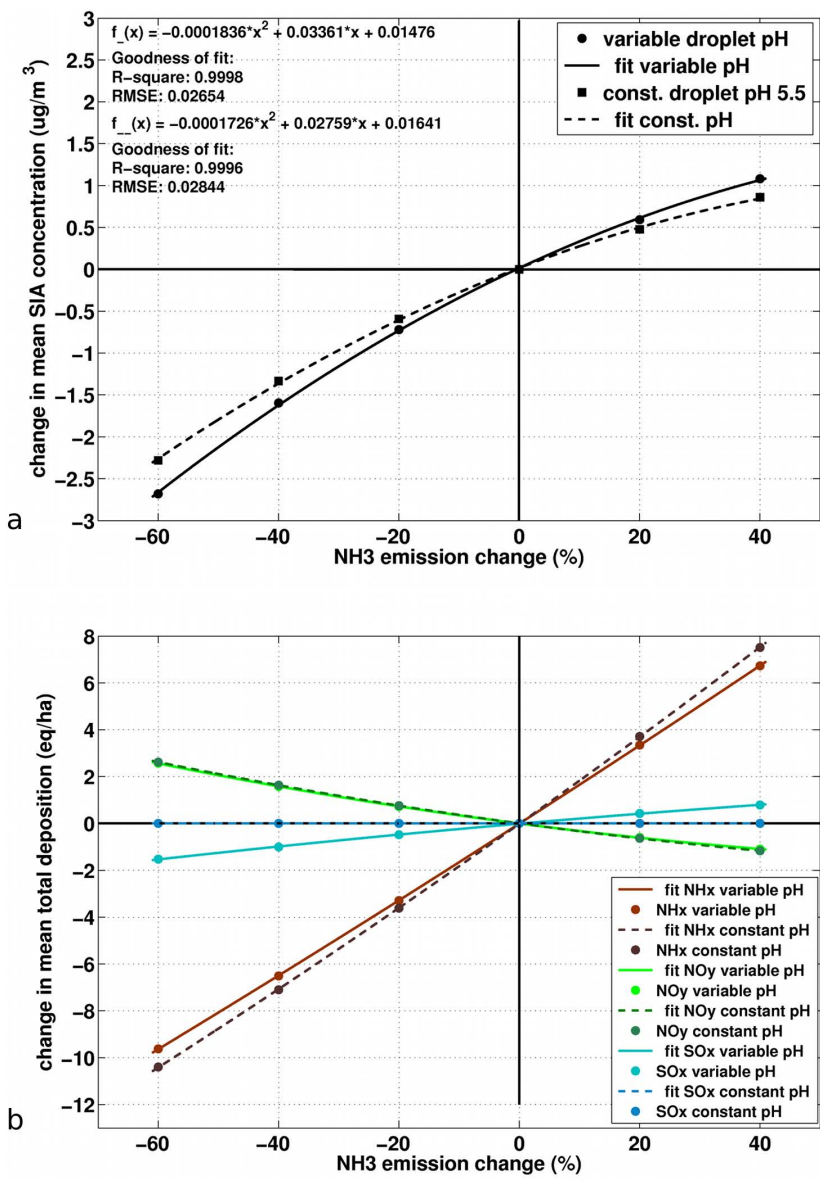

Fig. 12. Response of (a) the mean modelled SIA concentration and (b) the mean modelled $\mathrm{SO}_{\mathrm{x}}, \mathrm{NO}_{\mathrm{y}}$ and $\mathrm{NH}_{\mathrm{x}}$ total deposition in the German domain to ammonia emission changes using a variable (solid line) or constant (dashed line) droplet $\mathrm{pH}$.

the change in S compounds is most significant between GD and ED scenario runs. The total S deposition is reduced by $-42.6 \%,-8.7 \%$ and $-47.5 \%$ and the total $\mathrm{N}$ deposition by $-8.8 \%,-19.8 \%$ and $-29.9 \%$ for the $-\mathrm{NO}_{\mathrm{x}}-\mathrm{SO}_{2 \mathrm{ED}}$, $\mathrm{NH}_{3} \mathrm{ED}$ and $-\mathrm{NH}_{3}-\mathrm{NO}_{\mathrm{x}}-\mathrm{SO}_{2} \mathrm{ED}$ scenario runs, respectively.

\subsubsection{Response to ammonia emission changes}

Following the findings of Sect. 4.3.2 the response of SIA concentrations and $\mathrm{S}$ and $\mathrm{N}$ deposition fluxes to ammonia emission changes has been further investigated. The applied emission scenarios are summarised in Table 3.

Figure 11a shows base case average SIA concentration of the investigation period. Average SIA concentrations were highest in and around the Ruhr area. Figure $11 \mathrm{~b}$ and c shows the absolute and relative SIA reduction compared to the base case when reducing $\mathrm{NH}_{3}$ by $40 \%$ on the German domain. The highest absolute reduction of average SIA concentrations of more than $3 \mu \mathrm{g} \mathrm{m}^{-3}$ is achieved south of the Ruhr area where average SIA concentrations were high. The high- est relative reduction amounts up to $22 \%$ in the southwestern part of the domain. The comparison of absolute and relative SIA reduction to the $\mathrm{NH}_{3}$ emission map in Fig. 1c clearly shows that the $\mathrm{NH}_{3}$ measure leads to highest SIA reduction in areas with moderate and low $\mathrm{NH}_{3}$ emission densities. In ammonia-rich areas in northwestern and southeastern Germany the reduction is less distinct, however, it still amounts to more than $10 \%$.

In Fig. 12a, the change in average modelled SIA concentration within the German domain is plotted against the stepwise change in the $\mathrm{NH}_{3}$ emissions using modelled droplet $\mathrm{pH}$ (solid line) and a constant pH of 5.5 (dashed line). A polynomial curve was fitted through the data. The response of SIA concentrations on $\mathrm{NH}_{3}$ emission changes is non-linear. The larger the reduction of the $\mathrm{NH}_{3}$ emissions gets, the more effective the reductions in the SIA concentrations are. Compared to the base run, the change in average modelled SIA concentration amounts $-2.7 \mu \mathrm{g} \mathrm{m}^{-3}$ for the $-60 \% \mathrm{NH}_{3}$ run when applying a modelled droplet $\mathrm{pH}$. When a constant $\mathrm{pH}$ of 5.5 is used, a decrease in the mean modelled SIA concentration of $-2.3 \mu \mathrm{g} \mathrm{m}^{-3}$ is obtained. Hence, using a modelled droplet $\mathrm{pH}$, the model simulates $\mathrm{NH}_{3}$ emission reductions to be about $20 \%$ more effective in reducing SIA concentrations than when using a constant $\mathrm{pH}$. A reduction of $\mathrm{NH}_{3}$ emissions leads to reduced neutralisation of cloud acidity and consequently to less sulfate production, which is not accounted for using a constant droplet $\mathrm{pH}$. The impact of the consideration of droplet $\mathrm{pH}$ on model results has been extensively described in an earlier publication (Banzhaf et al., 2012). It was found that modelled droplet $\mathrm{pH}$ ranges between 3 and 8. While the oxidation of dissolved $\mathrm{SO}_{2}$ by $\mathrm{H}_{2} \mathrm{O}_{2}$ is independent of $\mathrm{pH}$, the oxidation pathway via ozone is highly dependent on droplet $\mathrm{pH}$ (Seinfeld and Pandis, 1998). For $\mathrm{pH}$ values higher than 5 the reaction rate of the ozone oxidation pathway reaches the same order as that of the $\mathrm{H}_{2} \mathrm{O}_{2}$ oxidation pathway and exceeds the latter for $\mathrm{pH}$ values higher than $\sim 5.7$. Hence, for $\mathrm{pH}$ values higher than 5 sulfate formation increases considerably with increasing droplet $\mathrm{pH}$. Hence, the assumed constant droplet $\mathrm{pH}$ described only the low $\mathrm{pH}$ cases correctly.

Figure $12 \mathrm{~b}$ shows the average total $\mathrm{SO}_{\mathrm{x}}, \mathrm{NO}_{\mathrm{y}}$ and $\mathrm{NH}_{\mathrm{x}}$ deposition within the German domain. The response of $\mathrm{SO}_{\mathrm{x}}$, $\mathrm{NO}_{\mathrm{y}}$ and $\mathrm{NH}_{\mathrm{x}}$ total deposition fluxes on ammonia emission changes is non-linear, similar as with the SIA concentrations. Only marginal changes in total $\mathrm{SO}_{\mathrm{x}}$ deposition occur when ammonia emissions are varied and a constant droplet $\mathrm{pH}$ is used. Applying a modelled droplet $\mathrm{pH}$, total $\mathrm{SO}_{\mathrm{x}}$ deposition varies with varying ammonia emissions. As for the sulfate concentrations, the reason is the missing feedback between ammonia concentrations and droplet $\mathrm{pH}$. $\mathrm{NO}_{\mathrm{y}}$ total deposition shows no dependency on droplet $\mathrm{pH}$. However, ammonia emission reductions result in an increase of the total $\mathrm{NO}_{\mathrm{y}}$ deposition. Ammonia emission reduction leads to less ammonium-nitrate formation and hence to higher $\mathrm{HNO}_{3}$ concentrations. The latter results in a significant increase 
of $\mathrm{HNO}_{3}$ dry deposition, which increases $\mathrm{NO}_{\mathrm{y}}$ deposition fluxes. Reducing ammonia emissions leads to a decrease of the total $\mathrm{NH}_{\mathrm{x}}$ deposition flux and vice versa for increased ammonia emissions. Reductions of the total $\mathrm{NH}_{\mathrm{x}}$ deposition flux are larger for the model runs using a constant $\mathrm{pH}$ than for the model runs using a modelled droplet $\mathrm{pH}$. This is because a decrease in ammonia emissions leads to a decrease of the droplet $\mathrm{pH}$. Hence, ammonia is wet scavenged more effectively and the decrease in $\mathrm{NH}_{\mathrm{x}}$ deposition is less effective.

\section{Discussion and conclusions}

In this study the response of modelled SIA concentrations to changes in precursor gas emissions during two high PM episodes over central Europe in spring 2009 has been investigated. The applied CTM, i.e. RCG, performed well in capturing the temporal variation of the $\mathrm{PM}_{10}$ and SIA concentrations. The model was successfully used to analyse the origin, development and characteristics of the investigated episodes.

The two SIA episodes were of different origin. For the first episode SIA was mainly formed outside the German domain. Hence, changes in ammonia emissions within the German domain did not impact SIA concentrations in Germany as severely as changes on the European domain. Within the second episode the sensitivity of SIA concentrations to changes in ammonia emissions in the German domain indicated that the high SIA concentrations originated from local sources within the German domain. The response of modelled SIA concentrations and connected deposition fluxes to precursor emission changes was non-linear. The response was found to be more linear for total deposition fluxes of sulfur and nitrogen than for SIA concentrations. Our knowledge on the constituents' non-linear relationships and interactions needs to be further improved and ideally implemented in our models. The latter is fundamental in order to be able to assist policy-makers to develop sustainable mitigation strategies and adapt the latter to seasonal and spatial variations in the emission pattern (West et al., 1999; Tsimpidi et al., 2007). Hence, models with linearised chemistry (e.g. OPS (Operational Priority Substances) model; Van Jaarsveld, 2004) are not suitable for this purpose.

The impact of national measures compared to Europeanwide mitigation efforts has been studied by means of several reduction scenarios with decreased emissions within the German domain only or within the European domain. Important source areas are located upwind of Germany and long range transport adds a significant fraction to the locally formed SIA. Therefore, decreasing emissions on the European domain (ED scenario runs) is more effective for all performed emission scenarios in reducing SIA concentration and total deposition fluxes than reducing emissions on the German domain (GD scenario runs). The difference between GD and ED scenario runs is more severe for pollutants that are affected to a large extent by long-range transport as e.g. $\mathrm{SO}_{2}$. This outcome confirms that a European-wide mitigation strategy is essential to achieve substantial pollutant concentration reductions.

As $\mathrm{NH}_{3}$ is more local than $\mathrm{SO}_{2}$ and $\mathrm{NO}_{\mathrm{x}}$ the effectiveness of $\mathrm{NH}_{3}$ emission reduction shows the least difference between GD and ED scenario runs. Sulfate and nitrate concentrations are only slightly reduced when reducing emissions of $\mathrm{SO}_{2}$ and $\mathrm{NO}_{\mathrm{x}}$ simultaneously on the German domain. Although $\mathrm{SO}_{2}$ German domain emissions are reduced by $50 \%$ the resultant sulfate reduction is slightly less than the reduction in sulfate when $\mathrm{NH}_{3}$ emissions are reduced by $40 \%$. The latter reduction in sulfate concentrations results solely from a reduced neutralisation of cloud acidity. Moreover, the simultaneous $\mathrm{NO}_{\mathrm{x}}$ and $\mathrm{SO}_{2}$ emission reductions lead to increased $\mathrm{OH}$ levels, which counteract the sulfate reduction as the rate of homogeneous oxidation of $\mathrm{SO}_{2}$ is increased (Tarrasón et al., 2003; Derwent et al., 2009). On average aqueous-phase formation is responsible for more than half of ambient atmospheric sulfate (Karamachandani and Venkatram, 1992; McHenry and Dennis, 1994). Locally, in the presence of clouds aqueous-phase sulfate production dominates over gas-phase sulfate formation while for sunny cloud-free conditions gas-phase sulfate formation is the dominant sulfate formation pathway. Additionally, the $\mathrm{NO}_{\mathrm{x}}$ reduction is partly compensated by an increase in ammoniumnitrate due to the $\mathrm{SO}_{2}$ emission reduction. Furthermore, the increase in $\mathrm{OH}$ levels also reduces the nitrate response as it leads to an increased conversion of $\mathrm{NO}_{\mathrm{x}}$ to $\mathrm{HNO}_{3}$ counteracting for the decrease in $\mathrm{NO}_{\mathrm{x}}$ (Fagerli and Aas, 2008). In contrast, nitrate is significantly reduced as soon as $\mathrm{NH}_{3}$ emissions are reduced. The results demonstrate that national $\mathrm{NH}_{3}$ measures in addition to EU-wide efforts in Germany are more effective to reduce SIA concentrations and deposition fluxes than additional national measures on $\mathrm{SO}_{2}$ and $\mathrm{NO}_{\mathrm{x}}$.

The potential of control strategies concerning SIA and PM reduction is strongly connected to the specific emission regime of the investigated region. We have found that $\mathrm{NH}_{3}$ measures lead to highest SIA reduction in areas with moderate and low $\mathrm{NH}_{3}$ emission densities. In these regions SIA formation is limited by the availability of $\mathrm{NH}_{3}$ while in ammonia-rich areas SIA formation is limited by $\mathrm{HNO}_{3}$. Following a reduction of $\mathrm{NH}_{3}$ in these $\mathrm{HNO}_{3}$-limited regimes a sufficient amount of $\mathrm{NH}_{3}$ remains to neutralize the available $\mathrm{HNO}_{3}$.

The non-linear response in the emission-concentrations and the emission-deposition relationship has been subject of several investigations over Europe in the past two decades. Pay et al. (2012) suggested that control strategies concerning SIA in northwestern Europe should focus on reductions of $\mathrm{SO}_{2}$ and $\mathrm{NO}_{\mathrm{x}}$ emissions. However, the conclusion was drawn based on the analysis of the indicators "free ammonia" $\left(\mathrm{TNH}_{3}-2 \mathrm{SO}_{4}^{2-}\right.$; with $\mathrm{TNH}_{3}$ and $\mathrm{SO}_{4}^{2-}$ as concentrations in $\left.\mu \mathrm{mol} \mathrm{m}{ }^{-3}\right)$, "S-ratio" $\left(\mathrm{SO}_{2} /\left(\mathrm{SO}_{2}+\mathrm{SO}_{4}^{2-}\right)\right.$; with $\mathrm{SO}_{2}$ and 
$\mathrm{SO}_{4}^{2-}$ as concentrations in $\mu \mathrm{g} \mathrm{m}^{-3}$ ) (Hass et al., 2003) and "G-ratio" ( $\left(\mathrm{TNH}_{3}-2 \mathrm{SO}_{4}^{2-}\right) / \mathrm{TNO}_{3}$; with $\mathrm{TNH}_{3}, \mathrm{SO}_{4}^{2-}$ and $\mathrm{TNO}_{3}$ as concentrations in $\mu \mathrm{mol} \mathrm{m}{ }^{-3}$ ) (Ansari and Pandis, 1998). These indicators do not include all sensitivities, e.g. $\mathrm{OH}$ interactions, which contribute to non-linearities in the sulfur and oxidised nitrogen budget (Tarrasón et al., 2003; Derwent et al., 2009). However, our findings are in line with earlier studies for different European regions (e.g. Tarrasón et al., 2003; Derwent et al., 2009; Erisman and Schaap, 2004; Builtjes et al., 2010) showing that $\mathrm{NH}_{3}$ emission reduction measures maintain a high reduction potential for SIA and therewith $\mathrm{PM}_{10}$ concentrations. The response of SIA concentrations on $\mathrm{NH}_{3}$ emission changes was found to be non-linear with an increasing SIA reduction effectiveness with increasing reduction of $\mathrm{NH}_{3}$ emissions. The latter was also found in the German PAREST project in which model runs for different scenarios were performed on an annual basis for the year 2005 (Builtjes et al., 2010). Tarrason et al. (2003) performed model runs for emission scenarios reducing German emissions of $\mathrm{NO}_{\mathrm{x}}(-25 \%)$ and $\mathrm{NH}_{3}(-25 \%)$ separately for the year 2000 using the EMEP model. The maximum reduction in annual mean SIA concentration following the $-25 \%$ $\mathrm{NH}_{3}$ emission reduction was about $1 \mu \mathrm{g} \mathrm{m}{ }^{-3}$. Considering that SIA concentrations peak in springtime, this is in good agreement with the maximum reduction in mean SIA concentrations (not shown here) of $1.3 \mu \mathrm{g} \mathrm{m}^{-3}$ for the $-20 \%$ $\mathrm{NH}_{3}$ emission scenario run in the investigation presented here. In addition to the SIA reduction stated by former studies, this study accounted for an additional sulfate reduction. When $\mathrm{NH}_{3}$ emissions are decreased, sulfate is reduced due to a reduced neutralisation of cloud acidity through the variable droplet $\mathrm{pH}$ approach (Banzhaf et al., 2012) as suggested by Redington et al. (2009). The incorporation of the explicit cloud chemistry adds more non-linearity to the system. All SIA components are sensitive to ammonia emission changes when using a modelled droplet $\mathrm{pH}$, while the change in SIA concentrations results solely from changes in nitrate and ammonium concentrations when assuming a constant droplet $\mathrm{pH}$.

Although RCG simulates the temporal development of the PM episodes well, some shortcomings of the model have been identified. The model was not able to capture the $\mathrm{PM}_{10}$ peaks, which is partly due to missing components in the modelled PM budget. In contrast, low $\mathrm{PM}_{10}$ levels are simulated too high. As the latter is not the case for the overall SIA concentrations, the reason for overestimation likely originates from the primary fraction. It was found that this overestimation is connected to high levels of wind blown dust for high wind speed conditions. As high PM levels during the investigation period occur at low wind speeds, high concentrations of wind blown dust do not occur during these episodes. The slight overestimation of sulfate concentrations can be partly attributed to an overestimation of modelled droplet $\mathrm{pH}$ leading to a too high rate of sulfate formation. Next to the buffering by carbon dioxide the effects of other buffering systems such as sea salt, mineral dust and organic components (Deguillaume et al., 2009) are not accounted for when modelling droplet pH (Banzhaf et al., 2012). In contrast to the sulfate concentrations, the nitrate concentrations are underestimated by RCG. This is partly connected to the overestimation of sulfate, which leads to a lower rate of ammonium-nitrate formation. Furthermore, evaluations of the applied equilibrium module ISORROPIA (Nenes et al., 1999) have indicated diverse shortcomings within the approach concerning the equilibrium between nitric acid and particulate ammonium nitrate (e.g. Schaap et al., 2011; Morino et al., 2006; Fisseha et al., 2006). The uncertainty in ammonia emission inventories in space and time (Geels et al., 2012) leads to an additional uncertainty in the modelled nitric acid-ammonium nitrate-equilibrium and the overall modelled SIA formation. Next to the uncertainty in space and time according to EMEP (2009) the uncertainty in magnitude of absolute annual ammonia emission values amounts about $\pm 30 \%$ in Europe. As non-linearities are to a large extent controlled by ammonia, the uncertainty in ammonia emissions severely impacts the modelled SIA budget. Also the correlations for the precursor gases $\mathrm{SO}_{2}$ and $\mathrm{NO}_{2}$ in air are encouraging as they show the ability of the model to capture the temporal variability of the analysed species concentrations. However, RCG tends to overestimate $\mathrm{SO}_{2}$ concentrations, while $\mathrm{NO}_{2}$ concentrations tend to be underestimated. As former studies have shown primary pollutants like $\mathrm{SO}_{2}$ and $\mathrm{NO}_{2}$ (which can be considered as almost primary pollutant as it is formed rapidly from emitted NO) are more difficult to model (Vautard et al., 2009). The evaluation of modelled $\mathrm{SO}_{\mathrm{x}}, \mathrm{NO}_{\mathrm{y}}$ and $\mathrm{NH}_{\mathrm{x}}$ wet deposition fluxes indicated a good model performance with correlation coefficients between 0.74 and 0.82 . The improvement of the spatial representation of precipitation of the meteorological driver may lead to a better representation of modelled wet deposition fluxes.

To further improve the performance of RCG, several options are identified: (1) inclusion of coarse nitrate from the reaction of $\mathrm{HNO}_{3}$ with soil and sea-salt particles (Pakkanen, 1996), (2) accounting for the co-deposition of $\mathrm{SO}_{2}$ and $\mathrm{NH}_{3}$ (Flechard et al., 1999) within the deposition routine, and (3) incorporation of the compensation point in the RCG dry deposition scheme (Wichink Kruit et al., 2010). The implementation of these processes may add further interdependencies and non-linear responses. The resultant variations in the response to emission changes need to be identified and understood. Therefore, a future study should expand the investigation period to several years/springs to better differentiate between episodes and non-episodes. In addition, a dynamic evaluation should be performed to investigate the ability of the model to correctly respond to emission changes. We are currently investigating the model performance for the 20 year period from 1990 to 2009 for this purpose. 
This study confirmed the important role of $\mathrm{NH}_{3}$ when considering reductions of SIA concentrations and deposition fluxes of sulfur and nitrogen compounds. The NEC Directive and the Gothenburg protocol provide national emission ceilings for $\mathrm{SO}_{2}, \mathrm{NO}_{\mathrm{x}}, \mathrm{NH}_{3}$ and VOC. Following the latest current legislation baseline, according to Amann et al. (2012), $\mathrm{SO}_{2}$ and $\mathrm{NO}_{\mathrm{x}}$ emissions will decrease significantly from 2010-2030 in the EU-27 $\left(\mathrm{SO}_{2}: \sim-70 \%\right.$; $\left.\mathrm{NO}_{\mathrm{x}}: \sim-65 \%\right)$ and Germany $\left(\mathrm{SO}_{2}: \sim-45 \% ; \mathrm{NO}_{\mathrm{x}}: \sim-65 \%\right)$ compared to 2005 emissions. $\mathrm{NH}_{3}$ emissions are expected to increase for the EU-27 $(\sim+2 \%)$ and for Germany $(\sim+11 \%)$. However, results of a "maximum technically feasible reduction" (MTFR) scenario show that available measures could reduce $\mathrm{NH}_{3}$ emissions significantly for the EU-27 ( -30\%) and Germany $(\sim-35 \%)$ compared to the current legislation baseline. The latter reveals that the $\mathrm{NH}_{3}$ reduction potential is not fully utilised yet. EU ammonia emission targets for 2010 and 2020 given by the NEC Directive and the Gothenburg protocol are not stringent enough and do not force the European member states policy to act on ammonia emission reduction. Next to the reduction potential the cost-effectiveness of measures needs to be considered. In Europe, costs for air pollution control including the costs for the current legislation baseline are significantly lower in the agricultural sector (which includes $\sim 95 \%$ of the total $\mathrm{NH}_{3}$ emissions) than in other sectors, where stringent emission control is already in force (Amann et al., 2011, 2012; Appelhans et al., 2012; Builtjes et al., 2010). Future negotiations for further emission reductions over Europe should focus on further implementation of sustainable and cost-effective $\mathrm{NH}_{3}$ measures.

Acknowledgements. This work was funded by TNO within the framework of the R\&D Project 371063246 -"PINETI" (Pollutant Input and Ecosystem Impact) - funded by the Federal Environment Agency (Umweltbundesamt, Germany). We thank the Federal Environment Agency (Germany), the RIVM (The Netherlands) and the EEA for providing the comprehensive measurement data and the German Weather Service (DWD) for providing COSMO-EU data. Further support was provided by Freie Universität Berlin.

Edited by: B. Ervens

\section{References}

Amann, M., Bertok, I., Borken-Kleefeld, J., Cofala, J., Heyes, C., Höglund-Isaksson, L., Klimont, Z., Rafaj, P., Schöpp, W., and Wagner, F.: Cost-effective Emission Reductions to Improve Air Quality in Europe in 2020. Analysis of Policy Options for the EU for the Revision of the Gothenburg Protocol. NEC Scenario Analysis Report \#8. International Institute for Applied Systems Analysis (IIASA), Laxenburg, Austria, 2011.

Amann, M., Borken-Kleefeld, J., Cofala, J., Heyes, C., Klimont, Z., Rafaj, P., Purohit, P., Schöpp, W., and Winiwarter, W.: Future Emissions of Air Pollutants in Europe - Current Legislation Baseline and the Scope for Further Reductions. TSAP Report No
1. International Institute for Applied Systems Analysis (IIASA), Laxenburg, Austria, 2012.

Ansari, A. S. and Pandis, S. N.: Responce of inorganic PM to precursor concentrations, Environ. Sci. Technol., 32, 2706-2714, 1998.

Appelhans, J., Builtjes, P., Jörß, W., Stern, R., and Theloke, J.: Exploring strategies to reduce particle concentrations- Results of the research project PAREST, Immissionsschutz 1-12, Erich Schmitt-Verlag Berlin, ISSN1430-9262, 2012.

Asman, W. A. H.: Modelling the atmospheric transport and deposition of ammonia and ammonium: an overview with special reference to Denmark, Atmos. Environ., 35, 1969-1983, 2001.

Banzhaf, S., Schaap, M., Kerschbaumer, A., Reimer, E., Stern, R., van der Swaluw, E., and Builtjes, P.: Implementation and evaluation of $\mathrm{pH}$-dependent cloud chemistry and wet deposition in the chemical transport model REM-Calgrid, Atmos. Environ., 49, 378-390, 2012.

Beekmann, M., Kerschbaumer, A., Reimer, E., Stern, R., and Möller, D.: PM measurement campaign HOVERT in the Greater Berlin area: model evaluation with chemically specified particulate matter observations for a one year period, Atmos. Chem. Phys., 7, 55-68, doi:10.5194/acp-7-55-2007, 2007.

Bobbink, R., Hornung, M., and Roelofs, J. M.: The effects of airborne pollutants on species diversity in natural and semi-natural European vegetation, J. Ecol., 86, 717-738, doi:10.1046/j.13652745.1998.8650717.x, 1998.

Builtjes, P., Jörß, W., Stern, R., and Theloke, J.: Strategien zur Verminderung der Feinstaubbelastung. PAREST-Summary report, FKZ 20643 200/01. UBA-Texte Nr. 09/2012. 2012 Umweltbundesamt, www.umweltbundesamt.de (last access: May 2013), 2010.

Carter, W. P. L.: Condensed atmospheric photooxidation mechanisms for isoprene. Atmos. Environ., 24, 4275-4290, 1996.

Claiborn, C., Lamb, B., Miller, A., Beseda, J., Clode, B., Vaughan, J., Kang, L., amd Newvine, C.: Regional measurements and modeling of windblown agricultural dust: The Columbia Plateau PM $_{10}$ Program, J. Geophys. Res., 103, 19753-19767, 1998.

Deguillaume, L., Tilgner, A., Schrödner, R., Wolke, R., Chaumerliac, N., and Herrmann, H.: Towards an operational aqueous phase chemistry mechanism for regional chemistry-transport models: CAPRAM-RED and its application to the COSMOMUSCAT model. J. Atmos. Chem., 64, 1-35, 2009.

de Meij, A., Thunis, P., Bessagnet, B., and Cuvelier, C.: The sensitivity of the CHIMERE model to emissions reduction scenarios on air quality in Northern Italy, Atmos. Environ., 43, 1897-1907, 2009.

Demuzere, M., Trigo, R. M., Vila-Guerau de Arellano, J., and van Lipzig, N. P. M.: The impact of weather and atmospheric circulation on $\mathrm{O}_{3}$ and $\mathrm{PM}_{10}$ levels at a rural mid-latitude site, Atmos. Chem. Phys., 9, 2695-2714, doi:10.5194/acp-9-2695-2009, 2009.

Denier van der Gon, H. A. C., Visschedijk, A., van den Brugh, H., and Dröge, R.: F\&E Vorhaben: Strategien zur Verminderung der Feinstaubbelastung - PAREST: A high resolution European emission data base for the year 2005, TNO-Report, TNO-034UT-2010-01895_RPT-ML, Utrecht, 2010.

Derwent, R. G., Witham, C. J., Redington, A. L., Jenkin, M., Stedman, J, Yardley, R., and Hayman, G.: Particulate matter at a rural 
location in southern England during 2006: model sensitivities to precursor emissions. Atmos. Environ., 43, 689-696, 2009.

EEA: Air quality in Europe - 2012 report. EEA Report No 4/2012. ISBN:978-92-9213-328-3. European Environment Agency (EEA), Copenhagen, Denmark, 2012.

EMEP: Transboundary, acidification, eutrophication and ground level ozone in Europe in 2007 EMEP August 2009, ISSN 15046192,2009

Erisman, J. W. and Schaap, M.: The need for ammonia abatement with respect to secondary PM reductions in Europe. Environ. Pollut., 129, 159-163, 2004.

Erisman, J. W., van Pul, A., and Wyers, P.: Parametrization of surface-resistance for the quantification of atmospheric deposition of acidifying pollutants and ozone. Atmos. Environ., 28, 2595-2607, 1994.

Erisman, J. W., Grennfelt, P., and Sutton, M.: The European perspective on nitrogen emission and deposition. Environ. Int., 29, 311-325, 2003

European Commission: European Commission. Directive 2008/50/EC of the European Parliament and of the Council of 21 May 2008 on ambient air quality and cleaner air for Europe. Technical Report 2008/50/EC, L152, Off. J. Eur. Commun, 2008.

Fagerli, H. and Aas, W.: Trends of nitrogen in air and precipitation: Model results and observations at EMEP sites in Europe, 19802003, Environ. Pollut., 154, 448-461, 2008.

Fisseha, R., Dommen, J., Gutzwiller, L., Weingartner, E., Gysel, M., Emmenegger, C., Kalberer, M., and Baltensperger, U.: Seasonal and diurnal characteristics of water soluble inorganic compounds in the gas and aerosol phase in the Zurich area, Atmos. Chem. Phys., 6, 1895-1904, doi:10.5194/acp-6-1895-2006, 2006.

Flechard, C. R., Fowler, D., Sutton, M. A., and Cape, J. N.: A dynamic chemical model of bi-directional ammonia exchange between semi-natural vegetation and the atmosphere, Q. J. Roy. Meteor. Soc., 125, 2611-2641, 1999.

Fountoukis, C. and Nenes, A.: ISORROPIA II: a computationally efficient thermodynamic equilibrium model for $\mathrm{K}^{+}, \mathrm{Ca}^{2+}, \mathrm{Mg}^{2+}, \mathrm{NH}_{4}^{+}, \mathrm{Na}^{+}, \mathrm{SO}_{4}^{2-}, \mathrm{NO}_{3}^{-}, \mathrm{Cl}^{-}, \mathrm{H}_{2} \mathrm{O}$ aerosols, Atmos. Chem. Phys., 7, 4639-4659, doi:10.5194/acp-7-46392007, 2007.

Fowler, D., Sutton, M., Flechard, C., Cape, J. N., Storeton-West, R. L., Coyle, M., and Smith, R. I.: The Control of $\mathrm{SO}_{2}$ Dry Deposition on to Natural Surfaces by $\mathrm{NH}_{3}$ and its Effects on Regional Deposition, Water Air Soil Poll., Focus, 1, 39-48, 2001.

Fowler, D., Müller, J., Smith, R. I., Cape, J. N., and Erisman, J. W.: Nonlinearities in source-receptor relationships for sulfur and nitrogen compounds, Ambio., 34, 41-46, 2005.

Fowler, D., Smith, R., Müller, J., Cape, J. N., Sutton, M., Erisman, J. W., and Fagerli, H.: Long-term trends in sulphur and nitrogen deposition in Europe and the cause of nonlinearities, Water Air Soil Poll., 7, 41-47, 2007

Geels, C., Andersen, H. V., Ambelas Skjøth, C., Christensen, J. H., Ellermann, T., Løfstrøm, P., Gyldenkærne, S., Brandt, J., Hansen, K. M., Frohn, L. M., and Hertel, O.: Improved modelling of atmospheric ammonia over Denmark using the coupled modelling system DAMOS, Biogeosciences, 9, 2625-2647, doi:10.5194/bg-9-2625-2012, 2012.
Gery, M. W., Whitten, G. Z., Killus, J. P., and Dodge, M. C.: A photochemical kinetics mechanism for urban and regional scale computer modeling, J. Geophys. Res., 94, 12925-12956, 1989.

Gipson, G. and Young, J.: Gas phase chemistry, Chapter 8 in: Science algorithms of the EPA models-3 community multiscale air quality (CMAQ) modeling system, Edited by: Byun, D. W. and Ching, J. K. S., Atmospheric Modeling Division National Exposure Research Laboratory US Environmental Protection Agency Research Triangle Park, NC 27711, EPA/600/R-99/030, 1999.

Gong, S. L., Barrie, L. A., and Blanchet, J.-P.: Modelling sea-salt aerosols in the atmosphere. 1. Model development. J. Geophys. Res., 102, 3805-3818, 1997.

Hass, H., van Loon, M., Kessler, C., Stern, R., Matthijsen, J., Sauter, F., Zlatev, Z., Langner, J., Foltescu, V., and Schaap, M.: Aerosol Modelling: Results and Intercomparison from 15 European Regional-scale Modelling Systems, EUROTRAC-2 Special report, Eurotrac-ISS, Garmisch Partenkirchen, Germany, 2003.

Karamachandani, P., and Venkatram, A.: The role of nonprecipitating clouds in producing ambient sulfate during summer: results from simulations with the Acid Deposition and Oxidant Model (ADOM), Atmos. Environ. 26A, 1041-1052, 1992.

Kuenen, J., Denier van der Gon, H., Visschedijk, A., van der Brugh, H., and van Gijlswijk, R.: MACC European emission inventory for the years 2003-2007. TNO report, TNO-060-UT-201100588, Utrecht, 2011.

Lövblad, G., Tarrasón, L., Tørseth, K., and Dutchak, S.: EMEP Assessment Part I: European Perspective. Norwegian Meteorological Institute, P.O. Box 43, N-313 Oslo, Norway, 2004.

Loosmore, G. A. and Hunt, J. R.: Dust resuspension without saltation. J. Geophys. Res., 105, 20663-20671, doi:10.1029/2000JD900271, 2000.

Matejko, M., Dore, A. J. Hall, J., Dore, C. J., Blas, M., Kryza, M., Smith, R., and Fowler, D.: The influence of long term trends in pollutant emissions on deposition of sulphur and nitrogen and exceedance of critical loads in the United Kingdom, Environ. Sci. Policy, 12, 882-896, 2009.

McHenry, J. N. and Dennis, R. L.: The relative importance of oxidation pathways and clouds to atmospheric ambient sulfate production as predicted by Regional Acid Deposition Model, J. Appl. Meteorol., 33, 890-905, 1994.

Morino, Y., Kondo, Y., Takegawa, N., Miyazaki, Y., Kita, K., Komazaki, Y., Fukuda, M., Miyakawa, T., Moteki, N., and Worsnop, D. R.: Partitioning of HNO3 and particulate nitrate over Tokyo: Effect of vertical mixing, J. Geophys. Res.-Atmos., 111, D15215, doi:10.1029/2005JD006887, 2006.

Mues, A., Manders, A., Schaap, M., Kerschbaumer, A., Stern, R., and Builtjes, P.: Impact of the extreme meteorological conditions during the summer 2003 in Europe on particle matter concentrations - an observation and model study, Atmos. Environ., 55, 377-391, 2012.

Nenes, A., Pilinis, C., and Pandis, S.: Continued development and testing of a new thermodynamic aerosol module for urban and regional air quality models, Atmos. Environ., 33, 1553-1560, 1999.

Pakkanen, T. A.: Study of formation of coarse particle nitrate aerosol, Atmos. Environ., 30, 2475-2482, 1996.

Pay, M. T., Jiménez, P., and Baldasano, J.: Assessing sensitivity regimes of secondary inorganic aerosol formation in Europe with 
the CALIOPE-EU modeling system, Atmos. Environ., 51, 146164, 2012.

Pinder, R. W., Adams, P. J., and Pandis, S. N.: Ammonia emission controls as a costeffective strategy for reducing atmospheric particulate matter in the eastern United States, Environ. Sci. Technol., 41, 380-386, 2007.

Pope, C. A.: Mortality effects of longer term exposures to fine particulate air pollution: review of recent epidemiological evidence, Inhal. Toxicol., 19 (Suppl. 1), 33-38, 2007.

Pope, C. A., Renlund, D. G., Kfoury, A. G., May, H. T., and Horne, B. D.: Relation of heart failure hospitalization to exposure to fine particulate air pollution, Am. J. Cardiol. 102, 1230-1234, 2008.

Putaud, J.-P., Raesa, F., Van Dingenen, R., Bruggemann, E., Facchini, M., Decesari, S., Fuzzi, S., Gehrig, R., Hueglin, C., Laj, P., Lorbeer, G., Maenhaut, W., Mihalopoulos, N., Mueller, K., Querol, X., Rodriguez, S., Schneider, J., Spindler, G., ten Brink, H., Torseth, K., and Wiedensohler, A.: A European aerosol phenomenology-2:chemical characteristics of particulate matter at kerbside, urban, rural and background sites in Europe, Atmos. Environ., 38, 2579-2595, 2004.

Putaud, J.-P., Van Dingenen, R., Alastuey, A., Bauer, H., Birmili, W., Cyrys, J., Flentje, H., Fuzzi, S., Gehrig, R., Hansson, H. C., Harrison, R. M., Herrmann, H., Hitzenberger, R., Huglin, C., Jones, A. M., Kasper-Giebl, A., Kiss, G., Kousa, A., Kuhlbusch, T. A. J., Löschau, G., Maenhaut, W., Molnar, A., Moreno, T., Pekkanen, J., Perrino, C., Pitz, M., Puxbaum, H., Querol, X., Rodriguez, S., Salma, I., Schwarz, J., Smolik, J., Schneider, J., Spindler, G., ten Brink, H., Tursic, J., Viana, M., Wiedensohler, A., and Raes, F.: A European aerosol phenomenology e 3: Physical and chemical characteristics of particulate matter from 60 rural, urban, and kerbside sites across Europe, Atmos. Environ., 44, 1308-1320, 2010.

Redington, A. L., Derwent, R. G., Witham, C. S., and Manning, A. J.: Sensitivity of modelled sulphate and nitrate aerosol to cloud, $\mathrm{pH}$ and ammonia emissions, Atmos. Environ., 43, 20, 32273234, 2009.

Renner, E. and Wolke, R.: Modelling the formation and atmospheric transport of secondary inorganic aerosols with special attention to regions with high ammonia emissions. Atmos. Environ., 44, 1904-1912, 2010.

Schaap, M., Otjes, R. P., and Weijers, E. P.: Illustrating the benefit of using hourly monitoring data on secondary inorganic aerosol and its precursors for model evaluation, Atmos. Chem. Phys., 11, 11041-11053, doi:10.5194/acp-11-11041-2011, 2011.

Schättler, U., Doms, G., and Schraff, C.: A description of the nonhydrostatic regional COSMO-model. Part VII: User's guide, Deutscher Wetterdienst, Offenbach, 135 pp., 2008.

Schell, B., Ackermann, I., Hass, H., Binkowski, F., and Ebel, A.: Modelling the formation of secondary organic aerosol within a comprehensive air quality model system, J. Geophys. Res., 106, 28275-28293, 2001.

Seinfeld, J. H. and Pandis, N.: Atmospheric Chemistry and Physics: From Air Pollution to Climate Change. From Air Pollution to Climate Change, John Wiley and Sons, Inc., New York, 1326 pp., 1998.

Solazzo, E., Biancini, R., Pirovano, G., Matthias, V., Vautard, R., Moran, M. D., Appel, K. W., Bessagnet, B., Brandt, J., Christensen, J. H., Chemel, C., Coll, I., Ferreira, J., Forkel, R., Francis, X. V., Grell, G., Grossi, P., Hansen, A. B., Miranda, A. I.,
Nopmongcol, U., Prank, M., Sartelet, K. N., Schaap, M., Silver, J. D., Sokhil, R. S., Vira, J., Werhahn, J., Wolke, R., Yarwood, G., Zhang, J., Rao, S. T., and Galmarini, S.: Operational model evaluation for particulate matter in Europe and North America in the context of AQMEII, Atmos. Environ., 53, 75-92, 2012.

Stern, R., Yamartino, R., and Graff, A.: Analyzing the response of a chemical transport model to emissions reductions utilizing various grid resolutions. In: Twenty-eighth ITM on Air Pollution Modelling and its Application, Leipzig, Germany, 15-19 May 2006, 2006.

Stern R., Builtjes, P., Schaap, M., Timmermans, R., Vautard, R., Hodzic, A., Memmesheimer, M., Feldmann, H., Renner, E., Wolke, R., and Kerschbaumer, A.: A model inter-comparison study focussing on episodes with elevated $\mathrm{PM}_{10}$ concentrations, Atmos. Environ., 42, 4567-4588, 2008.

Tarrasón, L., Johnson, J.E., Fagerli, H., Benedictow, A., Wind, P., Simpson, D., Klein, H.: EMEP Status Report 1/2003 - Part III: Source-Receptor Relationships, Transboundary acidification, eutrophication and ground level ozone in Europe, Norwegian Meteorological Institute, Oslo, 2003.

Thunis, P., Cuvelier, C., Roberts, P., White, L., Post, L., Tarrason, L., Tsyro, S., Stern, R., Kerschbaumer, A., Rouil, L., Bessagnet, B., Builtjes, P., Schaap, M., Boersen, G., and Bergstroem, R.: Evaluation of a Sectoral Approach to Integrated Assessment Modelling including the Mediterranean Sea, Eurodelta II report, Joint Research Center, Ispra, Italy, 2008.

Tsimpidi, A. P., Karydis, V. A., and Pandis, S. N.: Response of inorganic fine particulate matters to emission changes of $\mathrm{SO}_{2}$ and $\mathrm{NH}_{3}$ : the Eastern United States as a case study, J. Air Waste Manage., 57, 1489-1498, 2007.

UBA: Manual for Quality Assurance (in German), Texte 28/04, ISSN 0722-186X, Umweltbundesamt - Berlin, Fachgebiet II 5.6, 536 pp., 2004.

UBA: Auswertung der Luftbelastungssituation 2009. Fachgebiet II 4.2 Beurteilung der Luftqualität, Umweltbundesamt, DessauRoßlau, Germany, 2010.

van Dingenen, R., Raes, F., Putaud, J. P., Baltensperger, U., Brüggemann, E., Charron, A., Facchini, M. C., Decesari, S., Fuzzi, S., Gehrig, R., Hansson, H. C., Harrison, R. M., Hüglin, Ch., Jones, A. M., Laj, P., Lorbeer, G., Maenhaut,W., Palmgren, F., Querol, X., Rodríguez, S., Schneider, J., ten Brink, H., Tunved, P., Tørseth, K., Wehner, B., Weingartner, E., Wiedensohler, A., and Wåhlin, P. A.: European Aerosol Phenomenology I: Physical characteristics of particulate matter at kerbside, urban, rural and background sites in Europe. Atmos. Environ., 38, 2561-2577, 2004.

Van Jaarsveld, J. A.: The Operational Priority Substances model, description and validation of OPS-Pro 4.1, RIVM report 500045001/2004, Bilthoven, The Netherlands, 2004.

Vautard, R., Schaap, M., and Bergström, R.: Skill and uncertainty of a regional air quality model ensemble, Atmos. Environ., 43, 4822-4832, 2009.

Walcek, C. J.: Minor flux adjustment near mixing ratio extremes for simplified yet highly accurate monotonic calculation of tracer advection, J. Geophys. Res., 105, 9335-9348, 2000.

Weijers, E. P., Schaap, M., Nguyen, L., Matthijsen, J., Denier van der Gon, H. A. C., ten Brink, H. M., and Hoogerbrugge, R.: Anthropogenic and natural constituents in particulate mat- 
ter in the Netherlands, Atmos. Chem. Phys., 11, 2281-2294, doi:10.5194/acp-11-2281-2011, 2011.

West, J. J., Ansari, A. S., and Pandis, S. N.: Marginal PM 2.5 : Nonlinear Aerosol Mass Response to Sulphate Reductions in the Eastern United States, J. Air Waste Manage., 49, 1415-1424, 1999.
Wichink Kruit, R. J., Van Pul, W. A. J., Sauter, F. J., Van den Broek, M., Nemitz, E., Sutton, M. A., Krol, M., and Holtslag, A. A. M.: Modeling the surface-atmosphere exchange of ammonia, Atmos. Environ., 44, 945-957, 2010. 